\title{
Bromeliaceae do Parque Estadual da Serra do Rola-Moça, Minas Gerais ${ }^{1}$
}

\author{
Bromeliaceae of Serra do Rola-Moça State Park, Minas Gerais
}

\author{
Elidio Armando Exposto Guarçoni ${ }^{2}$, Cláudio Coelho de Paula ${ }^{2}$ \\ $\&$ Andrea Ferreira da Costa ${ }^{3}$
}

\begin{abstract}
Resumo
O Parque Estadual da Serra do Rola-Moça localiza-se na porção centro-sul da Cadeia do Espinhaço, na região denominada Quadrilátero Ferrífero, nos municípios de Belo Horizonte, Brumadinho, Ibirité e Nova Lima. Apresenta como vegetação os Campos Rupestres ferruginosos e quartizíticos, Floresta Estacional Semidecidual e Cerrado. O presente trabalho teve como finalidade estudar a florística da família Bromeliaceae no Parque Estadual da Serra do Rola-Moça. Foram identificadas 25 espécies pertencentes a 11 gêneros, sendo Dyckia o gênero mais representativo em espécies. Eduandrea selloana, Cryptanthus schwackeanus, Dyckia consimilis, D. densiflora, D. macedoi, D. simulans, D. schwackeana, D. trichostachya, Vriesea longistaminea e $V$. minarum encontram-se citadas na Listas das Espécies da Flora e da Fauna Ameaçadas de Extinção do Estado de Minas Gerais. Neste trabalho optamos por revalidar Dyckia oligantha.

Palavras-chave: Cadeia do Espinhaço, campo rupestre, Dyckia, Florística.
\end{abstract}

\begin{abstract}
The Serra do Rola-Moça State Park is located on the central southern portion of the Espinhaço Range, in a region denominated Quadrilátero Ferrífero (Iron Quadrangle). It comprises the municipalities of Belo Horizonte, Brumadinho, Ibirite and Nova Lima. The main vegetation types include the rocky grassland, semideciduous seasonal forest and savanna vegetation. This work aimed to study the floristics of the Bromeliaceae family in Serra do Rola-Moça State Park. Twenty-five species belonging to 11 genera were identified, and Dyckia is the most species-rich genus. Eduandrea selloana, Cryptanthus schwackeanus, Dyckia consimilis, D. densiflora, D. macedoi, $D$. simulans , D. schwackeana, D. trichostachya, Vriesea longistaminea and V. minarum are cited on the Minas Gerais Endangered Flora and Fauna Species List. Here we re-establish Dyckia oligantha as a species.
\end{abstract}

Key words: Espinhaço Range, rocky grasslands, Dyckia, floristics.

\section{Introdução}

Os Campos Rupestres caracterizam-se pela vegetação predominantemente herbáceo-arbustiva associada aos afloramentos rochosos e solos rasos e arenosos localizados geralmente acima de $900 \mathrm{~m}$, principalmente na Cadeia do Espinhaço (Giulietti et al. 1987; Harley 1995). Rizzini (1979) acrescenta que esta vegetação associa-se a afloramentos hematíticos, ou seja, desenvolve-se sobre substrato rico em ferro, na forma de concreções de sesquióxido de ferro, comum na região do Quadrilátero Ferrífero, em Minas Gerais, e na Serra dos Carajás, no Pará.
Bromeliaceae compreende ca. de 3.086 espécies e 56 gêneros (Luther 2006), tradicionalmente agrupadas em três subfamílias: Bromelioideae, Pitcairnoideae e Tillandsioideae. A família constitui um grupo de plantas cuja presença no ecossistema contribui para o aumento da diversidade biológica (Rocha et al. 2004). Este efeito é resultado de um complexo de características, pois as bromélias, neste contexto, são utilizadas por inúmeros animais como abrigo, fonte de alimento e refúgio (Rocha et al.2004).

Para o estado de Minas Gerais Versieux \& Wendt (2006) citam a ocorrência de 265 espécies

\footnotetext{
'Parte da dissertação de Mestrado em Botânica do primeiro autor, Universidade Federal de Viçosa, MG.

${ }^{2}$ Universidade Federal de Viçosa, Depto. Biologia Vegetal, 36570-000, Viçosa, MG. Autor para correspondência: elidioguarcone@oi.com.br

${ }^{3}$ Universidade Federal do Rio de Janeiro, Depto. Botânica, Museu Nacional, 20940-040, Rio de Janeiro, RJ.
} 
distribuídas em 27 gêneros, correspondendo a ca. de $9 \%$ do total das espécies da família. Grande parte desta riqueza concentra-se na Cadeia do Espinhaço de Minas Gerais. Nesta região, no Quadrilátero Ferrífero, é que a família merece especial atenção devido ao acelerado crescimento urbano e a atividade mineradora, que põem risco à conservação dos táxons endêmicos deste ambiente (Versieux \& Wendt 2007).

Dada a sua localização dentro do Quadrilátero Ferrífero e a diversidade de formações vegetacionais, o Parque Estadual da Serra do Rola-Moça (PESRM) caracteriza-se não só por uma significativa diversidade biológica, como também pelo alto grau de endemismos (Brandão et al. 1997; Meyer et al. 2004; Viana \& Lombardi 2007; Jacob et al. 2007).

Sendo assim, este trabalho teve como objetivo o estudo florístico das Bromeliaceae do PESRM, ampliando o conhecimento da família na área de estudo e no Quadrilátero Ferrífero. Estas informações são imprescindíveis ao adequado manejo, à implementação de ações de conservação de remanescentes e à restauração ecológica das áreas degradadas nestas localidades.

\section{Material e Métodos \\ Área de estudo}

O Parque Estadual da Serra do Rola-Moça (PESRM) localiza-se na região centro-sul do estado de Minas Gerais, nos municípios de Belo Horizonte, Brumadinho, Ibirité e Nova Lima (Meyer et al. 2004). Ocupa uma área de 3.941,09 ha, entre as coordenadas

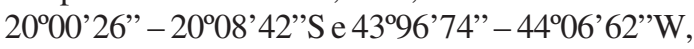
sendo constituído por quatro serras: Serra da Calçada, Serra do Cachimbo, Serra Ouro Fino e Serra do Rola-Moça (IBGE 1976, 1977).

Apresenta relevo irregular, com topografia que varia de suaves colinas levemente onduladas a trechos bastantes acidentados, com altitudes variando de 900 a $1450 \mathrm{~m}$, aproximadamente. O clima, segundo a classificação de Köppen é do tipo Cwa (tropical de altitude) caracterizado por inverno seco e verão chuvoso (Brandão et al. 1997). A temperatura média anual varia entre $18^{\circ}-21^{\circ} \mathrm{C}$. O regime pluviométrico apresenta variação de $1.300-2.100 \mathrm{~mm}$ de precipitação anual, sendo os meses de novembro, dezembro e janeiro os mais chuvosos e junho, julho e agosto os meses mais secos (Meyer et al. 2004).

No PESRM, a diversidade geológica, condicionou à formação de diferentes tipos de solos, que abrigam cada qual, um diferente tipo de vegetação: floresta estacional semidecidual Montana, preenchendo os vales, muitas vezes estendendo-se encosta acima; cerrado, subdividido em cerrado sensu stricto, encontrado nas áreas mais baixas do parque, em relevo plano ou ondulado, com solos mais profundos, e cerrado campo sujo, na grande maioria do parque, em geral nas regiões de relevo fortemente ondulados; e campos rupestres ferruginosos ou campo de canga (couraçado - substrato se apresenta na forma de lajeado; e nodular - substrato encontrase fragmentado) e quartizíticos, ocorrendo nas cotas mais altas, em relevo plano a suavemente ondulado (Rizini 1979; Veloso et al. 1991; Jacobi et al. 2007).

\section{Coleta e tratamento do material botânico}

A coleta do material botânico ocorreu entre janeiro de 2006 e dezembro de 2007. O material coletado foi herborizado de acordo com as técnicas usuais e encontra-se depositado no herbário (VIC). A identificação do material botânico foi fundamentada em literatura taxonômica, consulta a especialistas e comparação com material de identidade conhecida depositado nos seguintes herbários: VIC, OUPR, BHCB, PAMG, R, RB e HB. Fotos obtidas dos herbários B, P e US também foram analisadas (acrônimos segundo Holmgren \& Holmgren 1998).

Só foram citadas, no material examinado, exsicatas com procedência confirmada para dentro do perímetro do parque. A classificação adotada para subfamílias baseou-se em Smith \& Downs (1974, 1977, 1979). Para a confirmação dos nomes de gêneros e espécies usou-se Luther (2006). A terminologia morfológica adotada nas descrições foi baseada em Radford et al. (1974) e Brown \& Gilmartin $(1984,1989)$.

As descrições das espécies basearam-se apenas no material coletado dentro do Parque. Na ausência de determinadas estruturas no material examinado, as mesmas foram consideradas como não vistas. A medida da altura foi tomada a partir de indivíduos floridos. Os frutos foram citados, observados ou não, de acordo com suas características dentro de suas respectivas subfamílias. Foram priorizados para as ilustrações táxons pouco ilustrados e que apresentam problemas em suas delimitações.

A distribuição geográfica está baseada em Smith \& Downs (1974, 1977, 1979), Versieux \& Wendt (2006) e Martinelli et al. (2008), além de observações extraídas de herbário. Os estados onde ocorrem os táxons estão representados por suas respectivas siglas.

O status de conservação está baseado na Revisão das Listas das Espécies da Flora e da Fauna Ameaçadas de Extinção do Estado de Minas Gerais (Fundação Biodiversitas 2007). 


\section{Resultados e Discussão}

No PESRM foram identificadas 25 espécies de Bromeliaceae, reunidas em 11 gêneros, abrangendo três subfamílias. Bromelioideae está representada por sete gêneros (Aechmea Ruiz \& Pav., Ananas Mill., Billbergia Thunb., Bromelia L., Cryptanthus Otto \& A. Dietr., Eduandrea Leme, W. Till, G.K. Br., J.R. Grant \& Goyaens e Pseudananas Hassl. ex Harms), seguida por Tillandsioideae (Tillandsia L. e Vriesea Lindl.) e por Pitcairnioideae (Dyckia Schult.f. e Pitcairnia L'Hér.), ambas com dois gêneros. Dyckia mostrou-se o gênero mais representativo, com dez espécies. Das 25 espécies identificadas, duas, Bromelia sp. e Dyckia sp., não foram descritas nem incluídas na chave, pois não floresceram durante o trabalho. Bromelia sp. e Dyckia sp.1 não floresceram durante o trabalho e por isso, não foram descritas e nem incluídas na chave. Estes indivíduos encontram-se em cultivo na Unidade de Pesquisa e Conservação de Bromeliaceae (UPCB) da Universidade Federal de Viçosa (UFV) para posteriores determinações taxonômicas.

Das espécies encontradas no PESRM, 10 espécies encontram-se citadas na Revisão das Listas das Espécies da Flora e Fauna Ameaçadas de Extinção do Estado de Minas Gerais (Fundação Biodiversitas 2007): Dyckia schwackeana, Eduandrea selloana e Vriesea longistamine a como Criticamente em Perigo (CR); D. macedoi como Em Perigo (EN); Cryptanthus schwackeanus e V. minarum como Vulneráveis (VU); e D. consimilis, D. densiflora, D. simulan e $D$. trichostachya como Deficientes de Dados (DD).

\section{Chave para identificação das espécies de Bromeliaceae do PESRM}

1. Ovário súpero, fruto cápsula, sementes com apêndices.

2. Margens foliares inteiras.

3. Roseta formando tanque. Presença de apêndices petalíneos.

4. Escapo longo $(99,1 \mathrm{~cm})$. Apêndice petalíneo linear ................22. Vriesea longistaminea

4'. Escapo curto $(36,6-44,7 \mathrm{~cm})$. Apêndice petalíneo obtuso ou mucronado

23. Vriesea minarum

3'. Roseta não formando tanque. Ausência de apêndices petalíneos.

5. Escapo com uma única bráctea. Inflorescência uniflora

20. Tillandsia recurvata

5'. Escapo com várias brácteas. Inflorescência pluriflora.

6. Inflorescência composta. Brácteas florais triangulares ..... 19. Tillandsia gardneri

6'. Inflorescência simples. Brácteas florais ovadas

21. Tillandsia stricta

2'. Margens foliares serrilhadas ou serradas.

7. Pétalas livres; coloração verde-avermelhada

17. Pitcairnia lanuginosa

7'. Pétalas concrescidas na base; coloração laranja, avermelhadas ou castanho-escura.

8. Inflorescência congesta

13. Dyckia simulans

8'. Inflorescência laxa.

9. Brácteas florais maiores que as flores

9'. Brácteas florais menores que as flores.

10. Estames livres acima do anel pétalo-estamíneo.

11. Brácteas florais inteiras. Pétalas castanho-escuras .... 14. Dyckia tenebrosa

11'. Brácteas florais fimbriadas.

12. Lâmina triangular; ca. 3,5cm compr., densamente ferrugíneotomentosa na face abaxial. Brácteas escapais ovadas, acuminadas

9. Dyckia macedoi

12'. Lâmina linear-triangular, 5,4-16,4cm compr., cinéreo-lepidota com metade superior glabra na face adaxial. Brácteas escapais elípticas, agudo-apiculadas

10. Dyckia oligantha

10’. Estames conatos acima do anel pétalo-estamíneo.

13. Filetes conatos $5-6 \mathrm{~mm}$

7. Dyckia consimilis

13'. Filetes conatos $2-3 \mathrm{~mm}$.

14. Brácteas superiores do escapo iguais ou maiores que os entrenós .... 12. Dyckia schwackeana

14'. Brácteas superiores do escapo menores que os entrenós. 
15. Escapo densamente ferrugíneo-tomentoso. Brácteas florais serrilhadas ...... 8. Dyckia densiflora

15'. Escapo esparsamente cinéreo-tomentoso. Brácteas florais fimbriadas 11. Dyckia saxatilis

1'. Ovário ínfero, fruto bacáceo ou composto, semente sem apêndices.

16. Inflorescência séssil.

17. Folhas densamente lepidotas em ambas as faces. Pétalas com um par de calosidades

6. Cryptanthus tiradentesensis

17'. Folhas densamente lepidotas apenas na face abaxial. Pétalas sem calosidades

5. Cryptanthus schwackeanus

16'. Inflorescência escaposa.

18. Flores com ovários fundidos entre si. Fruto composto.

19. Inflorescência sem coma apical

18. Pseudananas sagenarius

19'. Inflorescência com coma apical

2. Ananas ananassoides

18'. Flores com ovários livres. Fruto baga.

20. Flores sésseis, estames inclusos.

21. Inflorescência estrobiliforme; escapo densamente branco-lanuginoso

1. Aechmea bromeliifolia var. bromeliifolia

21'. Inflorescência subglobosa; escapo esverdeado, branco-lepidoto 16. Eduandrea selloana

20'. Flores pediceladas, estames exsertos.

22. Escapo densamente branco-lanuginoso; pétalas revolutas na antese

4. Billbergia porteana

22’. Escapo glabro, pétalas curvas no ápice na antese

3. Billbergia elegans

1. Aechmea bromeliifolia (Rudge) Baker var. bromeliifolia, in Benth. \& Hook. f., Gen. Pl. 3: 664. 1883.

Erva epífita, rupícola ou terrestre, $88-144 \mathrm{~cm}$. Folhas 10-14, coriáceas; bainha elíptica a ovada, 16-25,8 $\times 4,7-14,8 \mathrm{~cm}$, creme a verde-acastanhada em ambas as faces, mácula roxa na face adaxial, lepidota na face abaxial, inteira; lâmina linear a lanceolada, 21-119,3 ×3-5,8 cm, verde na face abaxial, castanho-avermelhada na face adaxial, serrada, acúleos castanhos, 1,2-7 mm, antrorsos, agudo-apiculada. Escapo ereto, 70,2-90,3 cm, 0,8$1,2 \mathrm{~cm}$ diam., vinoso, branco-lanuginoso. Brácteas escapais oblongas a lanceoladas, 6,4-17×1-4,6 cm, inferiores eretas, brancas, superiores suberetas a patentes, róseas, inteiras, agudo-apiculadas. Inflorescência espiga estrobiliforme, $5,6-11,8 \mathrm{~cm}$ compr., 2,5-4 cm diâm., ereta. Brácteas florais ovadas, $0,7-0,9 \times 1,1-1,4 \mathrm{~cm}$, duas quilhas, castanhas, inteiras, branco-lanuginosas, coriáceas, truncadas. Flores numerosas, 1-1,4 cm, sésseis; sépalas ovadas, $8-9 \times 5 \mathrm{~mm}$, verdes a castanhas, branco-lanuginosas, inteiras, conatas na base, mucronadas; pétalas obovadas, ca. 1,2 $\times 0,6 \mathrm{~cm}$, amarelas, tornando-se pretas na pós-antese, dois apêndices petalíneos fimbriados, obtusas; estames inclusos, livres; filete ca. $1 \mathrm{~cm}$, amarelo-esverdeado; antera 4-5 mm, dorsifixa; ovário ínfero, verde; estilete ca. $8 \mathrm{~mm}$, verde; estigma conduplicadoespiral, ca. $2 \mathrm{~mm}$, branco. Frutos bacáceos.

Material examinado: BRASIL. MINAS GERAIS: Parque Estadual da Serra do Rola-Moça: Brumadinho, Retiro das Pedras - Serra da Calçada, 11.VIII.2001, fl., P.L. Viana 118 (BHCB); Serra da Calçada (1473 m), 15.VI.2006, fl., E. Guarçoni 1250 (VIC); Manancial do Catarina (1136 m), 26.VII.2006, fl., E. Guarçoni 12621263 (VIC); Ibirité, Pitangueiras (1135 m), 31.VII.2007, fl., E. Guarçoni 1300 (VIC); Nova Lima, Manancial do Mutuca, COPASA (1397 m), 16.VI.2006, fl., E. Guarçoni 1254-1255 (VIC).

Ocorre da América Central à Argentina. No Brasil ocorre nos seguintes estados: AM, AP, BA, CE, DF, GO, MA, MG, MS, MG, PA, PB, PR, RS, RO, RR, SC, SP e TO. Em MG ocorre nos Campos Rupestres, Cerrado e Mata Atlântica. No PESRM, Aechmea bromeliifolia ocorre nos Campos Rupestres Ferruginosos, dentro dos capões de mata, como epífita ou rupícola. Nos Campos Rupestres Quartizíticos ocorre nas fisionomias afloramentos rochosos e mata de galeria, como epífita ou rupícola. No Cerrado e nas Florestas Estacionais Semideciduais ocorre como epífita.

Pode ser confundida com Aechmea lamarchei Mez, distinguindo-se por apresentar lâminas foliares serradas ( $v s$. serrilhadas) e brácteas florais coriáceas e truncadas (vs. páleo-membranáceas e agudas) (Smith \& Downs 1979). 
2. Ananas ananassoides (Baker) L.B.Sm., Bot. Mus. Leafl. Harvard 7: 79, t.2. 1939.

Erva terrestre, 73,2-87,6 cm. Folhas 8-12, coriáceas, arqueadas; bainha oblonga, 4,9-12,8 $\times$ 3,6-5,5 cm, verde-pálida, serrilhada, acúleos menores que $1 \mathrm{~mm}$, densamente branco-lepidota em ambas as faces; lâmina linear, 78-79,8 8 1,9-2,2 $\mathrm{cm}$, verde-clara, serrada, acúleos castanhos, 1,2$1,9 \mathrm{~mm}$, antrorso-uncinados, canaliculada, lepidota em ambas as faces, acuminada. Escapo ereto, 47,6$52 \mathrm{~cm}$ compr., ca. $7 \mathrm{~mm}$ diâm., verde-escuro, densamente branco-lepidoto. Brácteas escapais lineares, 17,1-27,2 $\times 1-1,3 \mathrm{~cm}$, inferiores maiores que superiores, basais verdes, apicais avermelhadas, densamente lepidotas em ambas as faces, serradas, acúleos 1,5-2 mm, verdeacastanhados, antrorso-uncinados, agudas. Inflorescência espiga estrobiliforme, 3,3-3,8 cm compr., 2,2-4,9 cm diâm., ereta, coma apical róseo. Brácteas florais triangulares, 1-1,2 × 1,2-1,3 cm, excedendo as sépalas, róseas, serradas, acúleos 1,15-1,46 mm, castanho-avermelhados, brancolepidotas na face adaxial, concrescidas ao ovário por ca. 1,2 mm, acuminado-apiculadas. Flores numerosas, sésseis; sépalas triangulares, 5-6×5$7 \mathrm{~mm}$, róseas, branco-lepidotas na face abaxial, livres, inteiras, cuspidadas; pétalas espatuladas, $1,3-1,8 \times 0,2-0,3 \mathrm{~cm}$, violeta, livres, inteiras, 2 apêndices petalíneos fimbriados, obtusas; estames inclusos, livres; filetes $1-1,2 \mathrm{~cm}$, brancos, cilíndricos; antera linear, 4-5 mm, branca, dorsifixa; ovário ínfero, verde, pluricarpelar, sincárpico; estilete ca. 1,5 cm, branco; estigma conduplicadoespiral, ca. $2 \mathrm{~mm}$. Fruto composto.

Material examinado: BRASIL. MINAS GERAIS: Parque Estadual da Serra do Rola-Moça: Ibirité, Manancial do Rola-Moça, COPASA, 15.X.2007, fl., E. Guarçoni 1310 (VIC). Belo Horizonte, Manancial do Barreiro, COPASA, 15.X.2007, fl., E. Guarçoni 1319 (VIC).

Ocorre no Brasil, Argentina e Paraguai. No Brasil ocorre nos seguintes estados: AM, AP, CE, DF, GO, MG, MG, PA, RO, SP, MS, PB, PR, RJ e TO. Em MG ocorre nos Campos Rupestres, Cerrado e raramente na Mata Atlântica. No PESRM ocorre nas áreas de Cerrado, como terrestre.

Pode ser confundida com Ananas nanus (L.B.Sm.) L.B.Sm., diferindo pelo porte maior, escapo robusto ( $v s$. escapo delgado), muitas flores ( $v s$. poucas flores), coma apical pouco desenvolvido na antese ( $v s$. muito desenvolvido) e fruto maior ( $v s$. fruto menor) (Smith \& Downs 1979). Além disso, Smith \& Downs (1979) comentam que Ananas ananassoides ocorre em ambientes mais secos que $A$. nanus.
3. Billbergia elegans Mart. ex Schult. \& Schult.f. in Roem. \& Schult., Syst. veg. 7(2): 1265. 1830.

Erva rupícola, epífita ou terrestre, 63,6-74 cm. Folhas ca. 10, formando rosetas tubulares, coriáceas; bainha elíptica a ovada, 6,7-32,9×6,1-9,3 cm, creme com metade superior verde e mácula roxa na região central da face adaxial, lepidota em ambas as faces, inteira, ligeiramente demarcada por uma constrição; lâmina oblonga, 9,8-42,6 × 2,7-6,1 cm, verde a vermelha, lepidota em ambas as faces, serrada, acúleos 1-2 mm, antrorsos, obtuso-apiculada a agudoapiculada. Escapo ereto a subereto, 14,3-55,3 cm compr., 3-5 mm diâm., branco com terço superior verde-acastanhado, glabro, recoberto pelas brácteas escapais; Brácteas escapais elípticas a oblongas, 3,3$8,6 \times 2-4,9 \mathrm{~cm}$, inferiores menores que os entrenós, brancas a róseas, superiores mais longas que os entrenós, laranja a róseas, inteiras, ligeiramente serradas no ápice, agudo-apiculadas ou obtusoapiculadas. Inflorescência composta, 19,2-31 cm compr., 10,4-16 cm diâm., ereta, pendente pós-antese; ráquis laranja-avermelhada, castanha ou às vezes verde, glabra, geniculada ou não. Brácteas primárias elípticas, 5,4-8,5×1,8-4,1 cm, inferiores maiores que as flores, superiores menores que as flores, laranja a róseas, glabras ou lepidotas em ambas as faces, inteiras, agudo-apiculadas. Brácteas florais elípticas, triangulares ou obovadas, 1,2-2,5×0,6-1,1 cm, laranja, róseas ou vermelhas, agudo-apiculadas ou obtusas. Flores 6-26, 6,2-8,6cm; sépalas elípticas ou oblongas, 2,6-3×0,6-0,8 cm, laranja a róseas com ápice azul, inteiras, conatas na base, agudas, retusas ou obtusas; pétalas espatuladas a lineares, 4,5-5,9 ×0,4-0,6 cm, verdes com ápice azul, curvas no ápice na antese, dois apêndices petalíneos fimbriados, obtusas a mucronadas; estames exsertos, livres; filetes ca. 3,6 cm, verdes; anteras extrorsas, dorsifixas, 2-3 mm; ovário ínfero, 1,4-1,9 cm compr., 4-5 mm diâm., verde a verde-amarelado; estilete 4,7-5,5 cm, verde; estigma conduplicado-espiral, ca. $5 \mathrm{~mm}$, verde. Fruto bacáceo. Material examinado: BRASIL. MINAS GERAIS: Parque Estadual da Serra do Rola-Moça: Belo Horizonte, sopé da Serra do Cachimbo (1271 m), 15.II.2007, fl., E. Guarçoni 1293 (VIC). Brumadinho, Retiro das Pedras - Serra da Calçada, 28.X.1997, fl., A. Barros \& J.R. Stehmann 146 (BHCB); 06.XI.2001, fl., P.L. Viana 351 (BHCB); próximo ao Retiro das Pedras, 20.IV.2006, fl., E. Guarçoni 1258 (VIC); Ibirité, Serra do Rola-Moça (1367 m), 23.X.2006, fl., E. Guarçoni 1270, 1272 (VIC). Nova Lima, Campo Ferruginoso (1471 m), 21.I.2006, fl., E. Guarçoni 1240 (VIC); Campo de Canga Couraçada (1457 m), 20.IV.2006, fl., E. Guarçoni 1246-1247 (VIC); córrego Água da Chuva, 18.XII.2006, fl., E. Guarçoni 1288 (VIC). 
Martinelli et al. (2008) citam sua ocorrência somente para MG. Em MG ocorre nos Campos Rupestres, Cerrado e Mata Atlântica. No PESRM, Billbergia elegans é encontrada nos Campos Rupestres Ferruginosos Couraçados e Quartizíticos, como rupícola. Alguns indivíduos foram observados dentro dos capões de mata dos Campos Ferruginosos, como rupícolos ou epífitos, apresentando folha menos avermelhadas, às vezes verdes. Um espécime foi localizado como terrestre em Floresta Estacional Semidecidual.

Pode ser confundida com Billbergia amoena (Lodd.) Lindl. Segundo Smith \& Downs (1979), B. elegans difere de B. amoena por apresentar o escapo curvo ( $v s$. ereto), tomentoso ( $v s$. glabro) e pelas brácteas florais obtusas a obovadas, com as superiores iguais ou maiores que a metade do ovário ( $v s$. reniformes e inconspícuas). Entretanto, no PESRM, B. elegans apresenta escapo ereto a subereto e glabro.

4. Billbergia porteana Brongn. ex Beer, Fam. Bromel. 115. 1856.

Erva epífita, ca. $76 \mathrm{~cm}$. Folhas ca. 6, formando rosetas tubulares, coriáceas; bainha oblonga, 19-24 $\times 5,7-8,5 \mathrm{~cm}$, creme com mancha roxa na face adaxial, bandas brancas transversais na face abaxial, lepidota em ambas as faces, inteira; lâmina linear, 37-70,5× 3-3,1 cm, verde a verde-acinzentada com bandas transversais brancas, lepidota em ambas as faces, serrada, acúleos 2-5 mm, antrorso-uncinados, ereta, canaliculada, obtuso-apiculada. Escapo pendente, 73-80,3 cm compr., 7-8,7 mm diâm., verde, densamente branco-lanuginoso. Brácteas escapais lanceoladas a elípticas, 23,1-24,4 × 3,3-4,6 cm, inferiores maiores e estramíneas, superiores menores e vermelhas, inteiras, agudas. Inflorescência simples, 37-43,2 cm compr., ca. 13 cm diâm.; ráquis verde, densamente branco-lanuginosa. Brácteas florais inconspícuas, branco-lanuginosas. Flores ca. 9,5 cm compr., ca. 5 cm diâm.; sépalas ovadas, $7 \times 4-6 \mathrm{~mm}$, verdes, inteiras, livres, agudo-apiculadas; pétalas lineares, $6,4 \times 0,7 \mathrm{~cm}$, verdes, livres, dois apêndices petalíneos fimbriados, fortemente revolutas, agudas; estames exsertos, livres; filetes longos, ca. 4,2 cm, verde-claros com metade superior azulada; anteras extrorsas, basifixas, azuis, 2-2,5 cm; ovário ínfero, ca. $1 \mathrm{~cm}$ compr., ca. $8 \mathrm{~mm}$ diâm., verde, brancolanuginoso; estilete longo, ca. 7,3 cm; estigma conduplicado-espiral, ca. $7 \mathrm{~mm}$. Fruto bacáceo, 0,71,14 cm compr., 0,6-0,4 cm diâm, castanho.

Material examinado: BRASIL. MINAS GERAIS: Parque Estadual da Serra do Rola-Moça: Brumadinho,
Manancial da Catarina, COPASA, 15.X.2007, fr., E. Guarçoni 1309 (VIC). Nova Lima, Mutuca, 02.II.1933, fl., M. Barreto 2111 (BHCB); córrego da água da chuva, 20.IV.2006, fl., E. Guarçoni 1259 (VIC).

Ocorre no Brasil e Paraguai. No Brasil ocorre nos seguintes estados: BA, CE, DF, ES, MG, PB, PE, PI, SP e MG. Em MG ocorre nos Campos Rupestres e no Cerrado. No PESRM Billbergia porteana ocorre nas Florestas Estacionais Semideciduais, como epífita.

Pode ser confundida com Billbergia zebrina (Herb.) Lindl., diferindo pelo ovário elipsóide (vs. turbinado). Morren (1876, apud Versieux 2005) considerou como diferenças entre $B$. porteana e $B$. zebrina a folhagem mais clara, brácteas escapais mais amplas e vermelhas, flores mais espaçadas e a coloração mais azulada dos estames e estiletes.

\section{Cryptanthus schwackeanus Mez in Mart., Eichler} \& Urban, Fl. bras. 3(3): 203. $1891 . \quad$ Fig. $1 \mathrm{a}-\mathrm{e}$ Erva saxícola, 9,4-13,3 cm, caulescente, caule ereto a curvo, coberto pelas bainhas foliares. Folhas numerosas, subcoriáceas; bainha elíptica, 1,1-1,5 × 1,5-1,6 cm, verde-pálida, densamente branco-lepidota na face abaxial, serrada, acúleos 1,6-1,7 mm, irregularmente curvos; lâmina linear-triangular, 5,4-8,7 × 0,5-0,7 cm, verde-clara, densamente branco-lepidota na face abaxial, serrada, acúleos 1-2,2 $\mathrm{mm}$, irregularmente curvos, canaliculada, acuminada. Inflorescência composta, séssil; ramos basais com 2-3 flores, apicais com 1 flor, sésseis. Brácteas primárias semelhantes a lâmina, porém menores. Brácteas florais ovadas ou ligeiramente triangulares, 5-8 $\times 3-6 \mathrm{~mm}$, verdes, branco-lepidotas próximo ao ápice, inteiras, carenadas, agudas. Flores 1,6-1,8 cm, sésseis; sépalas oblongas, 5-6,4 × 2-2,5 mm, verde-pálidas, inteiras, 2,6-4,5 mm conatas, agudo-apiculadas; pétalas elípticas, 1-2,1 $\times 0,4-0,6 \mathrm{~cm}$, brancas, inteiras, ca. $2 \mathrm{~mm}$ conatas, agudas, estames inclusos, livres entre si, adnatos às pétalas, tetradínamos; filetes $1-1,3 \mathrm{~cm}$, brancos; anteras oblongas a ligeiramente sagitadas, 1,7-2,3 mm, amarelopálidas, dorsifixas; ovário ínfero, 2,4-5,2 mm compr., 1,7-3,6 mm diâm., verde-claro; estilete branco; estigma simples-ereto, 1,4-2,7 mm, branco. Fruto bacáceo.

Material examinado: BRASIL. MINAS GERAIS: Parque Estadual da Serra do Rola-Moça: Brumadinho, Serra da Calçada, próximo ao Retiro das Pedras, 29.IX.2006, fl., E. Guarçoni 1311 (VIC), 15.X.2007, fl., E. Guarçoni 1308 (VIC).

Ocorre nos Campos Rupestres de MG. Smith \& Downs (1979) também citam sua ocorrência para SP. Porém, na recente monografia da flora deste estado (Wanderley \& Martins 2007) a espécie não está incluída. No PESRM, Cryptanthus schwackeanus 


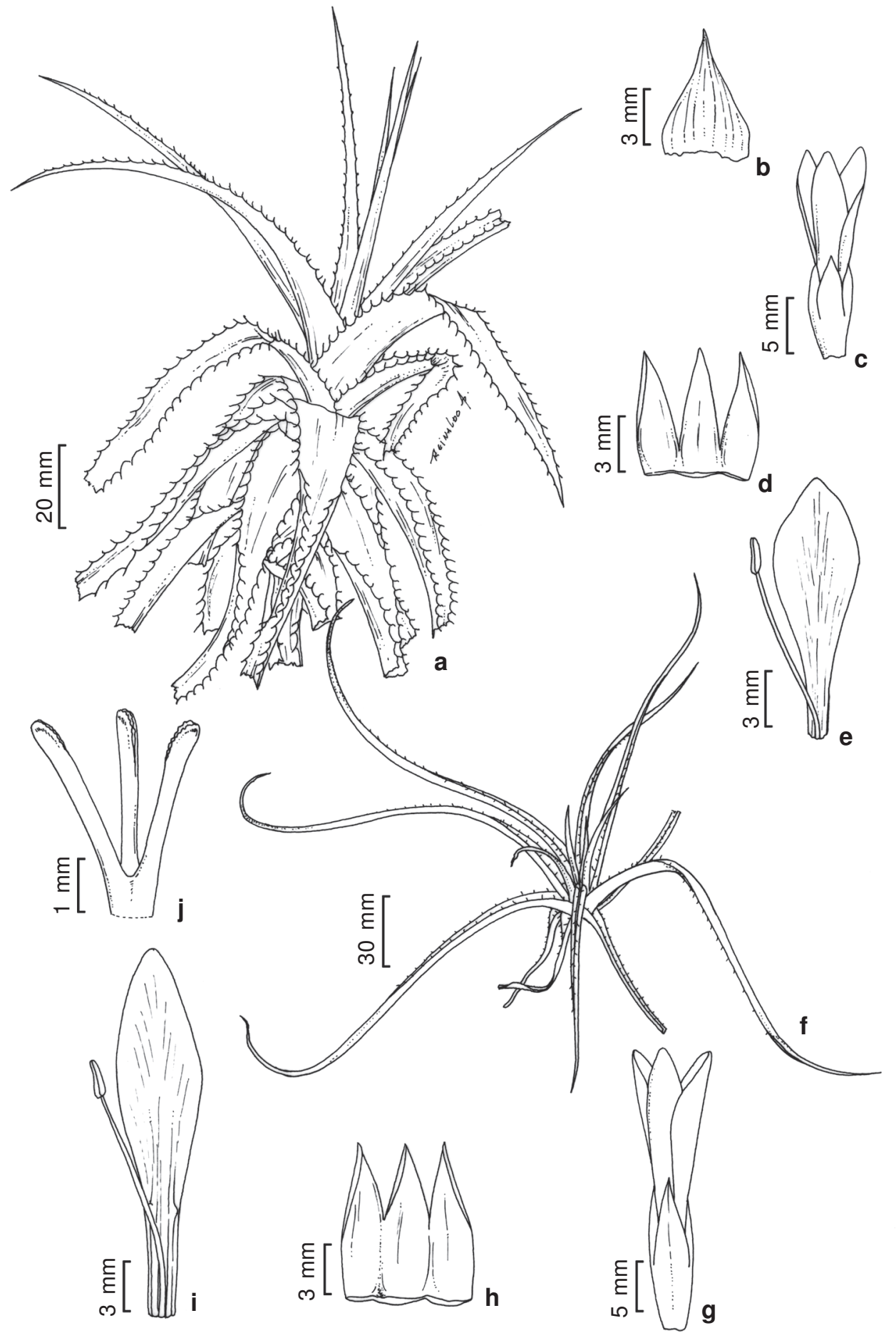

Figura 1 - a-e. Cryptanthus schwackeanus Mez - a. hábito; b. bráctea floral; c. flor; d. sépalas; e. detalhe da pétala e estame (Guarçoni 1308). f-j. C. tiradentesensis Leme-f. hábito; g. flor; h. sépalas; i. detalhe da pétala e estame entre o par de calosidades; j. estigma simples-ereto (Guarçoni 1286).

Figure 1 - a-e. Cryptanthus schwackeanus Mez - a. habit; b. floral bract; c. flower; d. sepals; e. detail of petals and stamen (Guarçoni 1308). f-j. C. tiradentesensis Leme - f. habit; g. flower; h. sepals; i. detail of petal and stamen between the calosities; j. stigma simpleerect type (Guarçoni 1286). 
foi observado como saxícola, nos Campos Rupestres Quartzíticos, na sua forma caulescente, geralmente crescendo à sombra, protegido pela angulação formada pela disposição das rochas, onde ocorre maior deposição de matéria orgânica.

Espécie bem documentada em herbários e muito variável, podendo apresentar-se acaulescente ou caulescente (Morrilo 1996). A forma caulescente foi observada por Morrilo (1996) em São Tomé das Letras e Mariana, MG. Cryptanthus schwackeanus está próximo de espécies da seção Hoplocryptanthus, podendo lembrar, vegetativamente, algumas formas de C. caracensis Leme \& Gross, acaulescentes, diferindo destas pela superfície foliar glabra na face adaxial (vs. lepidota) e folhas menos suculentas ( $v s$. suculentas) (Morrilo 1996). Cryptanthus schwackeanus também pode ser confundido com $C$. tiradentesensis Leme (ver comentário abaixo).

6. Cryptanthus tiradentesensis Leme, J. Bromeliad Soc. 57(6): 259-271. 2007.

Fig. $1 \mathrm{f}-\mathrm{j}$

Erva saxícola ou rupícola, 6-11,5 cm. Folhas 815, suberetas, coriáceas; bainha ovada a suborbicular, 1,4-2 $\times 0,6-2,2 \mathrm{~cm}$, branca a brancaesverdeada na face adaxial e castanha na face abaxial, densamente lepidota em ambas as faces, inteira com terço superior serreado; lâmina linear, 3-14,5 ×0,3$0,4 \mathrm{~cm}$, verde a verde-acastanhado na face abaxial com margens vermelhas, densamente lepidota em ambas as faces, serrada, acúleos menores que $1 \mathrm{~mm}$, antrorsos, canaliculada, acuminado-apiculada. Inflorescência composta, séssil; ramos com 2-3 flores. Brácteas primárias inconspícuas, foliáceas. Brácteas florais inconspícuas, densamente branco-lepidotas. Flores 2,7-3 cm compr., sésseis, odoríferas; sépalas ovadas, 6-9 × 2-3 mm, brancas a verde-alvas, densamente lepidotas na face abaxial, inteiras, canaliculadas, conatas na base por $4-5 \mathrm{~mm}$, acuminadas; pétalas espatuladas, $2,1-2,2 \times 0,6-0,7 \mathrm{~cm}$, brancas, inteiras, com um par de calosidades, conatas $1 \mathrm{~mm}$ na base, agudas ou obtusas; estames inclusos, conatos na base por $1 \mathrm{~mm}$ a um tubo comum com as pétalas; filetes 12-14 mm, brancos; anteras oblongas, ca. $3 \mathrm{~mm}$, brancas a amarelas, basifixas; ovário ínfero, 6-8 mm compr., ca. 4 mm diâm., branco a verde-alvo; estilete 1,4-1,9 cm, branco; estigma simples-ereto, 2-3 mm, branco. Fruto bacáceo.

Material examinado: BRASIL. MINAS GERAIS: Parque Estadual da Serra do Rola-Moça: Belo Horizonte, Serra do Cachimbo, 20.VI.2006, fl., E. Guarçoni 1286 (VIC). Brumadino, Serra da Calçada, 15.VI.2006, fl., E. Guarçoni 1251 (VIC); 1503 m, 27.XI.2006, fl., E. Guarçoni 1287 (VIC).
Endêmico de MG. Era conhecido apenas para a Serra de São José, em Tiradentes e São João Del Rey (Leme 2007). No PESRM, a espécie foi observada nos Campos Rupestres Ferruginosos Couraçados, geralmente nas fendas das lajes, por onde os rizomas se desenvolvem, atingindo um comprimento de ca. 30 $\mathrm{cm}$, ou protegido pela angulação formada pela disposição das rochas ferruginosas, geralmente na sombra. Foi observada no PESRM que a reprodução vegetativa ocorre com a produção de um ou dois clones por roseta, a 1-2 cm da planta mãe.

Espécie próxima de Cryptanthus schwackeanus, diferindo desta por apresentar folhas densamente lepidotas em ambas as faces ( $v s$. glabras na face adaxial), sépalas ovadas e maiores ( $v s$. oblongas e menores) e pétalas com calosidades ( $v s$. sem calosidades). Leme (2007) também comenta que essa espécie é próxima de $C$. caracensis Leme \& E.Gross, podendo ser distinguida por apresentar folhas menores e estreitas, brácteas florais duas a três vezes menores e distintamente menores que as sépalas (vs. igualando as sépalas), flores menores e por pétalas pouco conatas na base (1-2 $\mathrm{mm} v$ s. 5-7 $\mathrm{mm}$ ).

7. Dyckia consimilis Mez in Mart., Eichler \& Urban, Fl. bras. 3(3): 479. 1894.

Fig. $2 \mathrm{a}-\mathrm{g}$

Erva saxícola, ca. $27 \mathrm{~cm}$. Folhas numerosas, suberetas a eretas, coriáceas; bainha suborbicular, 0,9-1,0 × 1,4-1,6 cm, creme, serrada, acúleos menores que $1 \mathrm{~mm}$, antrorsos; lâmina triangular, 3,9$4,3 \times 0,5-0,6 \mathrm{~cm}$, verde com ápice castanho na face adaxial, densamente ferrugíneo-lepidota em ambas as faces, serrada, acúleos $1 \mathrm{~mm}$, patentes a ligeiramente antrorsos, canaliculada, acuminadoapiculada. Escapo ereto, ca. $17 \mathrm{~cm}$ compr., ca. $2 \mathrm{~mm}$ diam, vermelho, ferrugíneo-tomentoso. Brácteas escapais ovadas, $0,8-1 \times 0,3 \mathrm{~cm}$, menores que os entrenós, estramíneas, densamente ferrugíneolepidotas na face abaxial, metade inferior inteira, metade superior fimbriada, acuminado-apiculadas. Inflorescência simples, ca. 9,2 cm compr., ca. 2,8 cm diâm., ereta; ráquis vermelha, densamente ferrugíneotomentosa. Brácteas florais ovadas, 6-9 × $4 \mathrm{~mm}$, igualando as sépalas, laranja, lepidotas na face abaxial, fimbriadas, patentes a suberetas, acuminadas. Flores ca. 9, laxas, ca. 1,2 cm compr., ca. 4 mm diâm., basais suberetas e apicais patentes, pediceladas; pedicelo ca. $2 \mathrm{~mm}$; sépalas elípticas, 6-7 $\times 4 \mathrm{~mm}$, laranja, margens fimbriadas, suculentas, livres, obtusas; pétalas obovadas, 8-9 ×5-6 mm, laranja, inteiras, concrescidas na base, retusas; estames inclusos a ligeiramente exsertos por uma fração das anteras, ca. 

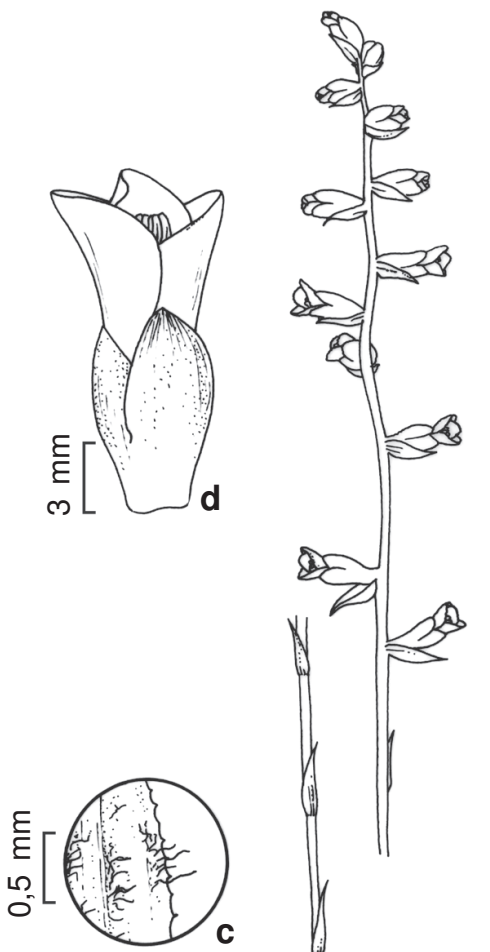

(1)
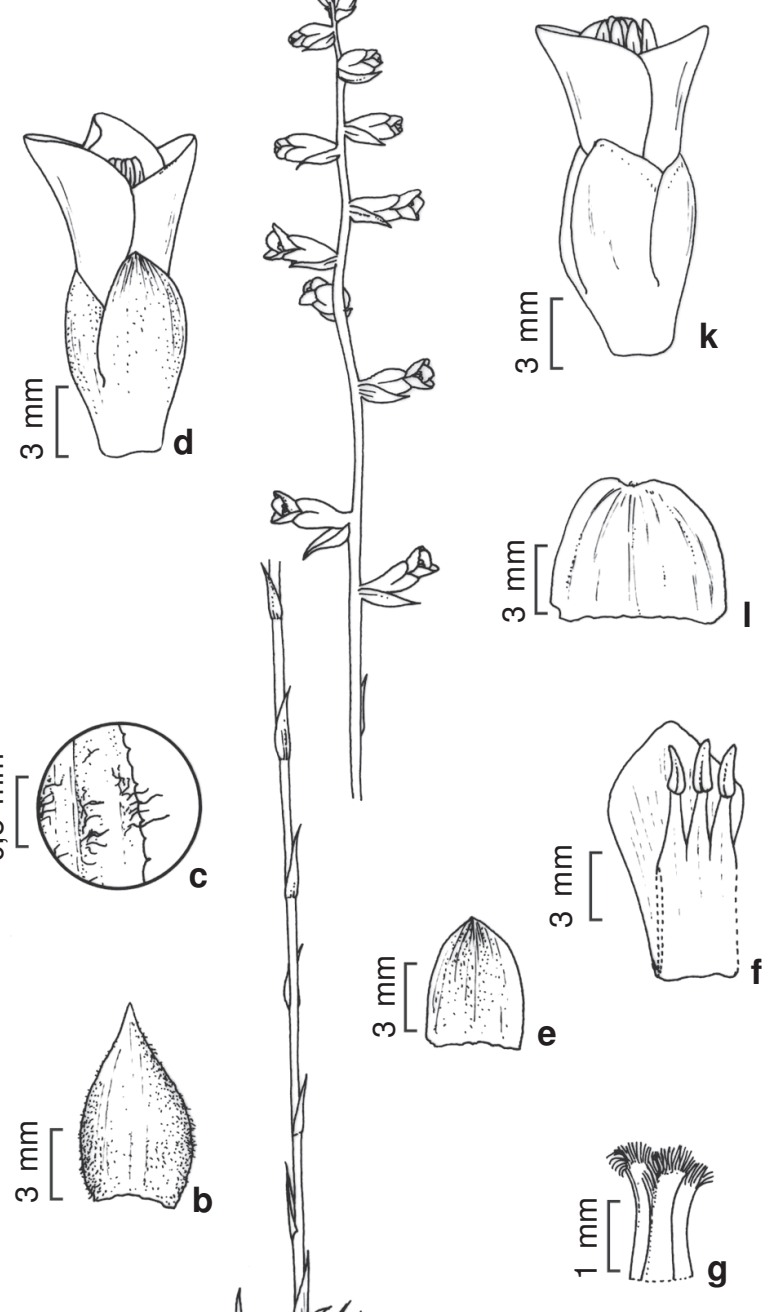
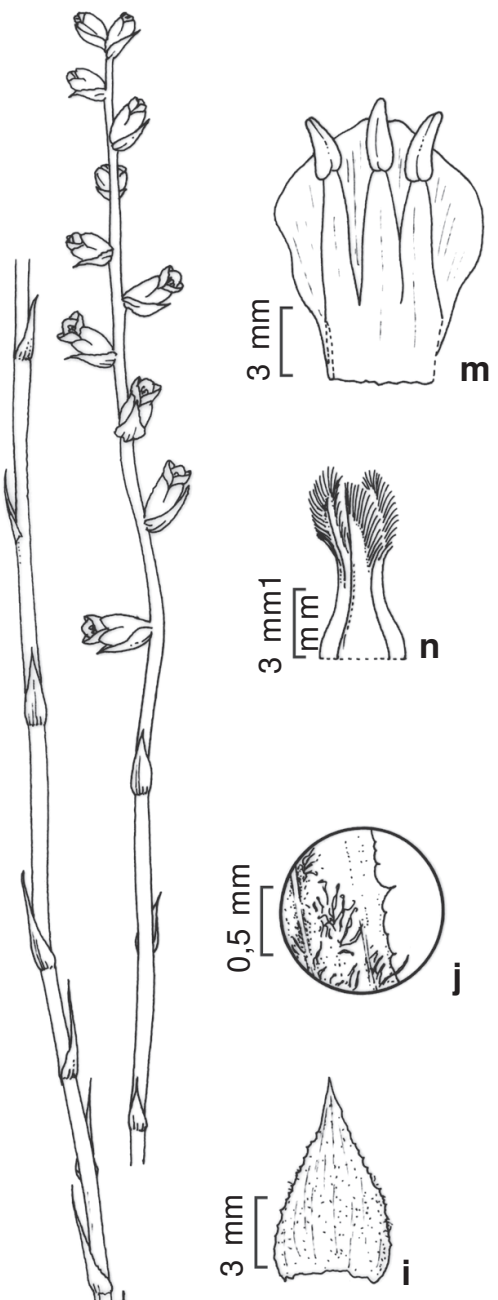

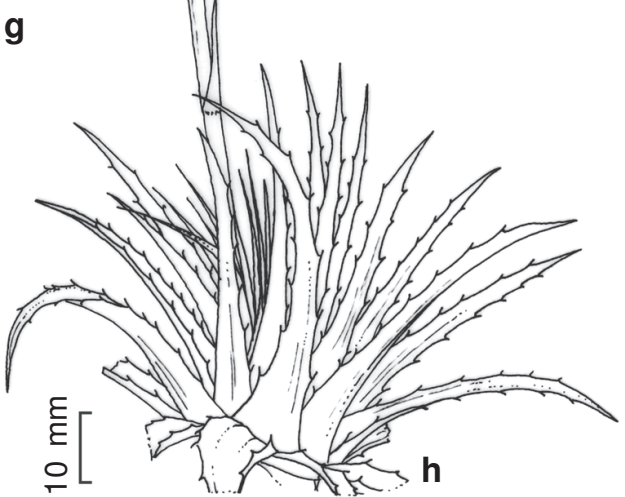

Figura 2 - a-g. Dyckia consimilis Mez - a. hábito; b. bráctea floral; c. detalhe da margem da bráctea floral; d. flor; e. sépala; f. detalhe da pétala com estames; g. estigma conduplicado-espiral (Guarçoni 1269). h-n. Dyckia densiflora Schult. f. - h. hábito; i. bráctea floral; j. detalhe da margem da bráctea floral; k. flor; 1. sépala; m. detalhe da pétala com estames; n. estigma conduplicado-espiral (Guarçoni 1252).

Figure 2 - a-g. Dyckia consimilis Mez - a. habit; b. floral bract; c. detail of floral bract margin; d. flower; e. sepal; f. detail of petal and stamens; g. stigma conduplicate-spiral type (Guarçoni 1269). h-n. Dyckia densiflora Schult. f. - h. habit; i. floral bract; j. detail of floral bract margin; k. flower; 1. sepal; m. detail of petal and stamens; n. stigma conduplicate-spiral type (Guarçoni 1252). 
$8 \mathrm{~mm}, 5-6 \mathrm{~mm}$ conatos acima do anel pétaloestamíneo; filetes complanados, ca. $6 \mathrm{~mm}$, amarelos; anteras triangulares, 2-3 mm, curvas no ápice, dorsifixas; ovário súpero, ca. $3 \mathrm{~mm}$, verde; estilete curto, verde; estigma conduplicado-espiral, ca. $1 \mathrm{~mm}$ compr. Fruto cápsula, 8-9 mm compr., 5-6 mm diâm., castanho escuro.

Material examinado: BRASIL. MINAS GERAIS: Parque Estadual da Serra do Rola-Moça: Belo Horizonte, Serra do Rola-Moça (1422 m), Serra do Cachimbo, 27.XI.2006, fl., E. Guarçoni 1279 (VIC). Brumadinho, Serra da Calçada (1503 m), 27.XI.2006, fl. e fr., E. Guarçoni 1283 (VIC). Ibirité, Serra do Rola-Moça (1363 m), 23.X.2006, fl., E. Guarçoni 1269 (VIC). Nova Lima, Serra do Curral, 18.I.1933, fl., M. Barreto 2103 (BHCB).

Ocorre nos Campos Rupestres da Cadeia do Espinhaço, em MG. No PESRM, Dyckia consimilis é facilmente encontrada, apresentando-se como saxícola no Campo Rupestre Ferruginoso Couraçado e no Campo Rupestre Quartzítico, onde forma pequenas touceiras, expondo seu rizoma.

Espécie semelhante a Dyckia macedoi L.B.Sm., D. saxatilis Mez (veja comentário desta última) e $D$. schwackeana Mez. Difere de $D$. schwackeana, a mais próxima, por apresentar lâmina foliar ferrugíneo-lepidota ( $v s$. cinéreo-lepidota), brácteas escapais menores que os entrenós e margem fimbriada (vs. maiores e serradas) e estames 5-6 mm conatos acima do anel pétalo-estamíneo (vs. 2 mm acima). Quanto à $D$. macedoi, difere por apresentar lâmina foliar ferrugíneolepidota ( $v s$. cinéreo-lepidota), brácteas escapais com margens fimbriadas ( $v s$. serrilhadas) e estames 5-6 mm conatos acima do anel pétalo-estamíneo ( $v s$. livres).

8. Dyckia densiflora Schult. \& Schult.f. in Roem. \& Schult., Syst. veg. 7(2): 1194. 1830. Fig. 2 h-n

Erva saxícola, 38,9-51 cm. Folhas coriáceas, suculentas, eretas e suberetas; bainha suborbicular, 1,1-1,7×2,1-3,0 cm, creme-amarronzada, margens serradas, acúleos menores que $1 \mathrm{~mm}$, patente a retrorsos; lâmina triangular, 5,8-7,6×0,6-0,7 cm, metade inferior verde a verde-acinzentada e metade superior castanha, densamente cinéreo-lepidota na face abaxial, laxamente serrada, acúleos ca. $2 \mathrm{~mm}$, antrorsos, canaliculada, acuminado-apiculada. Escapo ereto, 26,5-39 cm compr., 2-3 mm diâm., castanho, densamente ferrugíneo-tomentoso. Brácteas escapais ovadas, 0,7-4,4 ×0,2-0,4 cm, inferiores maiores que os entrenós, superiores menores, estramíneas, densamente lepidotas na face abaxial, serrilhadas, acúleos menores que $1 \mathrm{~mm}$, laxas, acuminadas. Inflorescência simples, 8,5-9,5 cm compr., 2-3 mm diâm., ereta; ráquis castanha a castanha- avermelhada, ferrugíneo-tomentosa. Brácteas florais elípticas a ovadas, $4-7 \times 3-5 \mathrm{~mm}$, inferiores igualando as sépalas, laranja a laranja-avermelhadas, densamente lepidotas na face abaxial, serrilhadas, acúleos menores que $1 \mathrm{~mm}$, carenadas, retusas. Flores 9-15, 1,2-1,5 cm compr., ca. 5 mm diâm., suberetas a patentes, pediceladas; pedicelos robustos, 2-3 mm.; sépalas elípticas a ovadas, $0,7-1,2 \times 0,5-0,8 \mathrm{~cm}$, laranja a laranja-avermelhadas, lepidotas na face abaxial, fimbriadas, livres, agudas; pétalas obovadas a elípticas, 0,9-1,3×0,5-1 cm, laranja, superfície ondulada próximo as margens, concrescidas na base, obtusas; estames inclusos ou exsertos por uma fração da antera, conatos 2-4 mm acima do anel pétalo-estamíneo; antera triangular, 0,9-1,1 cm. amarela, dorsifixa; filetes complanados, afinando para o ápice, 4-9 $\times 2 \mathrm{~mm}$, amarelos; ovário súpero, 0,5-1,1 cm compr., ca. $2 \mathrm{~mm}$ diâm., verde; estilete curto, ca. 1 mm compr.; estigma conduplicado-espiral, $1 \mathrm{~mm}$. Fruto cápsula, castanhoescuro, 1,0-1,2 cm compr., 6-9 mm diâm.

Material examinado: BRASIL. MINAS GERAIS: Parque Estadual da Serra do Rola-Moça: Brumadinho, Serra da Calçada (1499 m), 23.X.2006, fl., E. Guarçoni 1275 (VIC). Nova Lima, subida para a Serra da Calçada, 15.VI.2006, fr., E. Guarçoni 1252 (VIC), 15.VI.2006, fr., E. Guarçoni 1253 (VIC); Serra do Cachimbo, 01.VIII.2007, fl., E. Guarçoni 1302 (VIC).

Ocorre nos Campos Rupestres da Cadeia do Espinhaço, em MG. No PESRM, Dyckia densiflora é facilmente encontrada nos Campos Rupestres Ferruginosos, principalmente no Couraçado, onde forma touceiras centrífugas entremeadas a Vellozia sp., Laelia sp. ou Lychnophora sp.

Espécie que tipifica o gênero. Pode ser facilmente identificada pelo escapo densamente recoberto por tricomas ferrugíneos e por apresentar brácteas florais serrilhadas.

9. Dyckia macedoi L.B.Sm., Arq. Bot. Estado São Paulo 2: 195. $1952 . \quad$ Fig. 3 a-g

Erva rupícola ou saxícola, ca. 25,2 cm. Folhas numerosas, suculentas; bainha suborbicular, 0,8-1 × 1,1-1,3 cm, branca a creme, serrilhada; lâmina triangular, 3,5-6,2 ×0,5-0,6 cm, verde a verde-acinzentada com ápice castanho na face adaxial, densamente ferrugíneo-lepidota na face abaxial, serrada, acúleos $1 \mathrm{~mm}$, patentes a ligeiramente antrorsos, canaliculada, acuminadoapiculada. Escapo ereto, ca. 17,3 cm compr., ca. 2 $\mathrm{mm}$ diam, verde-avermelhado, ferrugíneotomentoso. Brácteas escapais ovadas, ca. 0,41,1× $0,1-0,9 \mathrm{~cm}$, inferiores iguais ou maiores que os entrenós, superiores menores, estramíneas, 


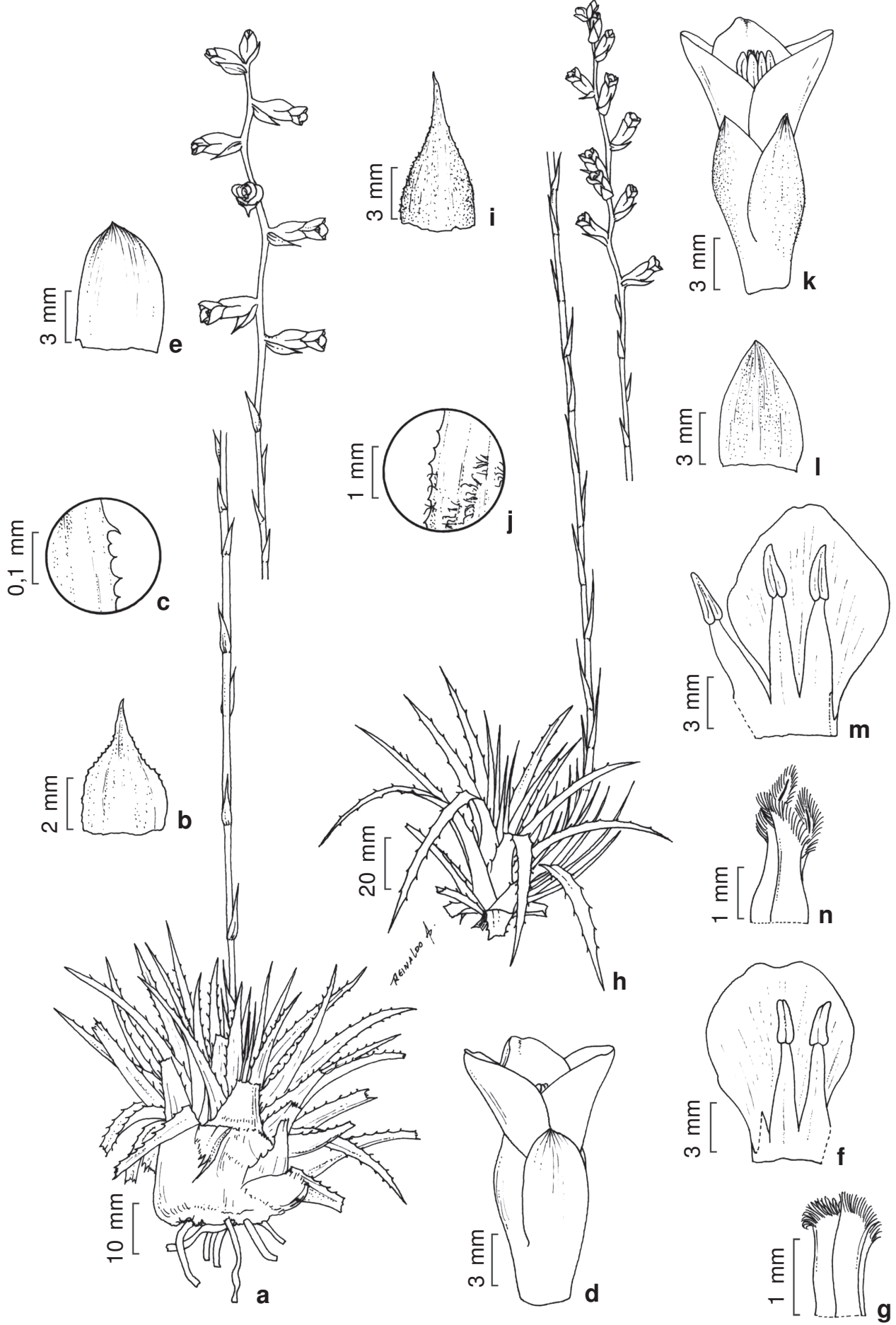

Figura 3 - a-g. Dyckia macedoi L.B.Sm - a. hábito; b. bráctea floral; c. detalhe da margem da bráctea floral; d. flor; e. sépala; f. detalhe da pétala com estames; g. estigma conduplicado-espiral (Guarçoni 1276). h-n. Dyckia oligantha L.B.Sm - h. hábito; i. bráctea floral; j. detalhe da margem da bráctea floral; k. flor; 1. sépala, m. detalhe da pétala com estames; n. estigma conduplicado-espiral (Guarçoni 1281).

Figure 3 - a-g. Dyckia macedoi L.B.Sm - a. habit; b. floral bract; c. detail of floral bract margin; d. flower; e. sepal; f. detail of petal and stamens; g. stigma conduplicate-spiral type (Guarçoni 1276). h-n. Dyckia oligantha L.B.Sm - h. habit; i. floral bract; j. detail of floral bract margin; k. flower; 1. sepal; m. detail of petal and stamens; n. stigma conduplicate-spiral type (Guarçoni 1281). 
densamente lepidotas na face abaxial, serrilhadas na região apical, laxas, acuminadas. Inflorescência simples, ereta, ca. 5,7 cm compr., ca. 2,8 cm diâm.; ráquis laranja a vermelha, densamente lepidota. Brácteas florais ovadas, 5-7 × 4-5 mm, menores que as sépalas, laranja, ferrugíneo-lepidotas na face abaxial, fimbriadas, carenadas, acuminadas. Flores ca. 8, 1,4-1,6 cm compr., 6-7 mm diâm., patentes, pediceladas; pedicelo $2-3 \mathrm{~mm}$; sépalas elípticas a ovadas, 7-8 $\times 4-5 \mathrm{~mm}$, laranja, lepidotas na face abaxial, fimbriadas, livres, obtusomucronadas; pétalas obovadas, $1-1,1 \times 0,6-0,9 \mathrm{~cm}$, laranja, concrescidas na base, obtusas a retusas; estames inclusos, 1-1,1 cm, livres acima do anel pétalo-estamíneo; filetes complanados, 7-8 mm, amarelos; antera triangular, 2-3 mm, dorsifixa; ovário súpero, $4 \mathrm{~mm}$, verde; estilete $2-3 \mathrm{~mm}$, verde; estigma conduplicado-espiral, 1-2 mm. Frutos cápsula.

Material examinado: BRASIL. MINAS GERAIS: Parque Estadual da Serra do Rola-Moça: Brumadinho, Serra da Calçada (1499 m), 23.X.2006, fl., E. Guarçoni 1276 (VIC); Retiro das Pedras, Serra da Calçada, sd., fl., L.A. Martens 62 (SPF).

Ocorre nos campos rupestres da Cadeia do Espinhaço, em MG. No PESRM, pode ser observada como saxícola no Campo Rupestre Ferruginoso Couraçado.

Pode ser confundida com Dyckia consimilis Mez (veja comentários da mesma) e D. brachyphylla L.B.Sm., que não ocorre no Parque, diferindo desta última por apresentar escapo ferrugíneo-tomentoso (vs. branco-tomentoso), brácteas escapais serrilhadas na região apical ( $v s$. inteiras) e flores pediceladas ( $v s$. subsésseis).

A espécie aqui tratada difere da descrição do material tipo (Smith 1952) e daquela apresentada por Forzza \& Wanderley (1998), por não apresentar pedicelos clavados e pela presença de indumento no escapo, que na literatura é tratado como glabro. A análise dos exemplares BHCB 25141 e 107666, identificados como Dyckia macedoi, mostra que os mesmos não apresentam pedicelos clavados. Provavelmente a forma dos pedicelos pode ser variável não sendo um caráter consistente para delimitar a espécie. Estudos taxonômicos devem ser efetuados para melhor compreensão de sua circunscrição.

10. Dyckia oligantha L.B.Sm, Arq. Jard. Bot. Rio de Janeiro 15: 329. 1958.

Fig. 3 h-n

Erva saxícola, $31-76 \mathrm{~cm}$. Folhas numerosas, suculentas; bainha ovada a elíptica, 0,5-1,7 ×0,9-2,6 $\mathrm{cm}$, branca-esverdeada, serrilhada, acúleos menores que $1 \mathrm{~mm}$; lâmina linear-triangular, 5,4-16,4×0,4-1 cm, verde a verde-acinzentada na face abaxial e verdeacastanhada na face adaxial, cinéreo-lepidota e glabra na metade superior, serrada, acúleos 1-2 mm, antrorso-uncinados, canaliculada, acuminadaapiculada. Escapo ereto, 13,5-48,4 cm comp., 3-4 mm diâm., verde a castanho, ferrugíneo-tomentoso. Brácteas escapais elípticas, 1,1-5,1 ×0,2-1,2 cm, inferiores maiores que os entrenós, verdes a castanhas, superiores menores, estramíneas, densamente ferrugíneo-tomentosas na face abaxial, serradas, algumas vezes fimbriadas entre os acúleos, acúleos $1 \mathrm{~mm}$, agudo-apiculadas a acuminadas. Inflorescência simples, ereta, 3,3-27,3 cm comp., 2$3,8 \mathrm{~cm}$ diâm.; ráquis castanha a vermelha, cinéreotomentosa. Brácteas florais ovadas a amplamente elípticas, 0,5-1 ×0,4-0,8 cm, laranja ou laranja com ápice castanho, ferrugíneo-lepidotas na face abaxial, fimbriadas, patentes a suberetas, carenadas, acuminadas. Flores 9-19, 1,2-1,7 cm comp., 4-8 mm diâm., suberetas, pediceladas; pedicelo 2-7 mm compr., 2-3 mm diâm., castanho; sépalas elípticas a ovadas, $0,6-1 \times 0,4-0,6 \mathrm{~cm}$, laranja a castanhoavermelhadas, ferrugíneo-tomentosas na face abaxial, fimbriadas, livres, agudas; pétalas obovadas, 0,6-1,3×0,4-0,7 cm, amarelas a laranja, superfície ondulada na região marginal, margem membranácea, inteiras com parte apical às vezes fimbriadas, concrescidas na base, agudas a obtusas; estames inclusos, $0,8-0,9 \times 1-1,1 \mathrm{~cm}$, livres acima do anel pétalo-estamíneo; filetes complanados, 4-8×2 mm, amarelo-pálido a amarelos; anteras ligeiramente triangulares, $2-4 \times 1 \mathrm{~mm}$, curvas, dorsifixas; ovário súpero, 0,6-1,1 cm comp., ca. $3 \mathrm{~mm}$ diâm., verde; estilete curto, 0,1-0,2 cm comp., verde ou amarelo-acastanhado; estigma conduplicado-espiral, 1-2 mm, amarelo. Fruto cápsula, elíptica a globosa, 1-1,2×0,7-1 cm, preto, brilhoso. Material examinado: BRASIL. MINAS GERAIS: Parque Estadual da Serra do Rola-Moça: Brumadinho, Serra da Calçada, 23.X.2006, fl., E. Guarçoni 1273-1274 (VIC); 27.XI.2006, fl., E. Guarçoni 1281 (VIC). Nova Lima, Serra da Calçada, subida para o campo ferruginoso, 21.I.2006, fl., E. Guarçoni 1241 (VIC).

No PESRM, Dyckia oligantha foi encontrada nas diversas fisionomias de Campo Rupestre, formando touceiras centrífugas ou com indivíduos isolados.

Espécie sinonimizada por Forzza \& Wanderley (1998) sob Dyckia saxatilis, à qual é extremamente semelhante, tanto no diâmetro da roseta quanto no tamanho da planta. Entretanto, os exemplares analisados apresentam bainha ovada a elíptica ( $v s$. 
suborbicular), lâmina com acúleos antrorsouncinados (vs. irregulares), pétalas com superfície ondulada na região marginal ( $v s$. não ondulada), ovário mais robusto ( $v s$. menos robusto), fruto mais robusto (vs. menos robusto)., bem como estames livres acima do anel pétalo-estamíneo (vs. 2-3 mm conatos).

Diante desta controvérsia, decidiu-se pela revalidação de Dyckia oligantha, já que a conação ou não dos estames acima do anel pétalo-estamíneo, é essencial para diferenciar as espécies dentro do gênero, segundo Smith \& Downs (1974).

11. Dyckia saxatilis Mez in C. DC., Monogr. phan. 9:518. 1896.

Fig. 4 a-g

Erva saxícola, $23,3-49,3 \mathrm{~cm}$. Folhas numerosas, suculentas; bainha suborbicular, 1-1,3×1,3-2,4 cm, branca a ligeiramente verde, serrilhada, acúleos menores que $1 \mathrm{~mm}$; lâmina linear-triangular, 8,7×0,4-0,7 cm, verde-acastanhada a verde-acinzentada, densamente cenéreo-lepidota em ambas as faces com metade superior adaxial glabra, ligeiramente canaliculada, serrada, acúleos 1-2 mm, irregularmente curvos, acuminado-apiculada. Escapo ereto, 22-39,5 cm compr., 3-5 mm diâm., verde com metade superior castanha ou vermelha, esparsamente cinéreotomentoso, anguloso. Brácteas escapais largoovadas a elípticas, $0,9-4,7 \times 0,4-1 \mathrm{~cm}$, inferiores maiores ou iguais aos entrenós, adensadas, superiores menores, estramíneas com a base castanha, esparsamente lepidotas na face abaxial, serrilhadas, acúleos menores que $1 \mathrm{~mm}$, acuminadoapiculadas. Inflorescência simples, ereta, 5,8-14 cm compr., 1,7-4 cm diâm., laxa; ráquis vermelha a castanha, cinéreo-tomentosa. Brácteas florais largoovadas a elípticas, 6-9×4-6 mm, menores ou iguais às sépalas, laranja com ápice castanho ou laranjaavermelhadas, densamente cinéreo-lepidotas na face abaxial, fimbriadas, suberetas, acuminadoapiculadas. flores 9-20, 1,2-1,9 cm compr., 4-7 mm diâm., suberetas a patentes, pediceladas; pedicelos 2-3 mm; sépalas ovadas a elípticas, 5-9 $\times 5-8 \mathrm{~mm}$, laranja a laranja-avermelhadas, cinéreo-tomentosas na face adaxial, fimbriadas, livres, obtusas a agudoapiculadas; pétalas obovadas, $0,7-1,3 \times 0,5-1 \mathrm{~cm}$, laranja, inteiras, concrescidas na base, obtusas a retusas; estames inclusos, conatos 2-3 mm acima do anel pétalo-estamíneo; filetes complanados, 5-9 mm, amarelos; anteras triangulares a ligeiramente elípticas, ligeiramente curvas, 2-4 mm, amarelas, dorsifixas; ovário súpero, 4-7 mm, verde; estilete 1-2 mm; estigma conduplicado-espiral, ca. $1 \mathrm{~mm}$, amarelo. Fruto cápsula, marrom, 0,8-1 cm compr., 3-4 mm diâm.
Material examinado: BRASIL. MINAS GERAIS: Parque Estadual da Serra do Rola-Moça: Belo Horizonte, Serra do Cachimbo, (1422 m), 27.XI.2006, fl., E. Guarçoni 1278 (VIC). Brumadinho, Retiro das Pedras, Serra da Calçada, 23.XI.1989, fl., L.A. Martens 368 (SPF); próximo ao Retiro das Pedras (1366 m), 26.VII.2006, E. Guarçoni 1261 (VIC); Serra da Calçada 29.VIII.2006, fl. e fr., E. Guarçoni 1268 \& B. Rodrigues (VIC); (1503 m), 27.XI.2006, fl., E. Guarçoni 1282 (VIC). Nova Lima, Campo Rupestre Ferruginoso, 20.IV.2006, (1453 m), fl., E. Guarçoni 1249 (VIC); Serra do Cachimbo (1463 m), 27.XI.2006, fl., E. Guarçoni 1277 (VIC).

Dyckia saxatilis ocorre em GO, MG e BA. Martinelli et al. (2008), entretanto, citam sua ocorrência somente para o estado de MG, onde ocorre nos Campos Rupestres, Cerrado e Mata Atlântica. No PESRM, D. saxatilis foi encontrada no campo rupestre ferruginoso couraçado como saxícola, crescendo em touceiras centrífugas.

Trata-se de uma espécie morfologicamente muito variável, que deve ser mais detalhadamente estudada para sua melhor delimitação. Pode ser confundida com Dyckia consimilis Mez e D. schwackeana Mez. Difere de D. consimilis por apresentar rosetas de diâmetro maior e não curvas, brácteas escapais inferiores amplamente ovadas a elípticas, adensadas ( $v s$. ovadas e sublaxas), maiores 1,5-2,7 (vs. 0,8-1), escapo robusto e angular (vs. delgado e cilíndrico), inflorescência laxa ( $v s$. subdensa), bráctea floral amplamente ovada a elíptica ( $v s$. ovada) e estames conatos 2-3 mm (vs. 5-6 mm conatos). Quanto a D. schwackeana, difere por apresentar rosetas de diâmetro maior, brácteas escapais superiores menores que os entrenós (vs. maiores), escapo robusto e angular ( $v s$. delgado e cilíndrico).

12. Dyckia schwackeana Mez in Mart., Eichler \& Urban, Fl. bras. 3(3): 478. $1894 . \quad$ Fig. 4 h-n

Erva saxícola, $25,2-37,3 \mathrm{~cm}$. Folhas numerosas, carnosas; bainha elíptica, 0,6-1,2 × 1,1-1,6 cm, branca, serrilhada, acúleos menores que $1 \mathrm{~mm}$; lâmina linear-triangular, 4,7-6,5×0,4-0,7 cm, verde a castanha, densamente cinéreo-lepidota em ambas as faces, serrada, acúleos 1-2 mm, patentes a antrorsos, ligeiramente canaliculada, acuminadoapiculada. Escapo ereto, 16,8-23,8 cm compr., 1-3 mm diâm, verde a castanho, cinéreo-tomentoso. Brácteas escapais amplamente ovadas a elípticas, 0,7-3,2 × 0,3-0,4 cm, maiores que os entrenós, estramíneas, algumas vezes com base vermelha, lepidotas na face abaxial, serradas, acúleos 1-2 mm compr., irregularmente curvos, acuminadas. Inflorescência simples, ereta, 3,5-6,9 cm compr., 

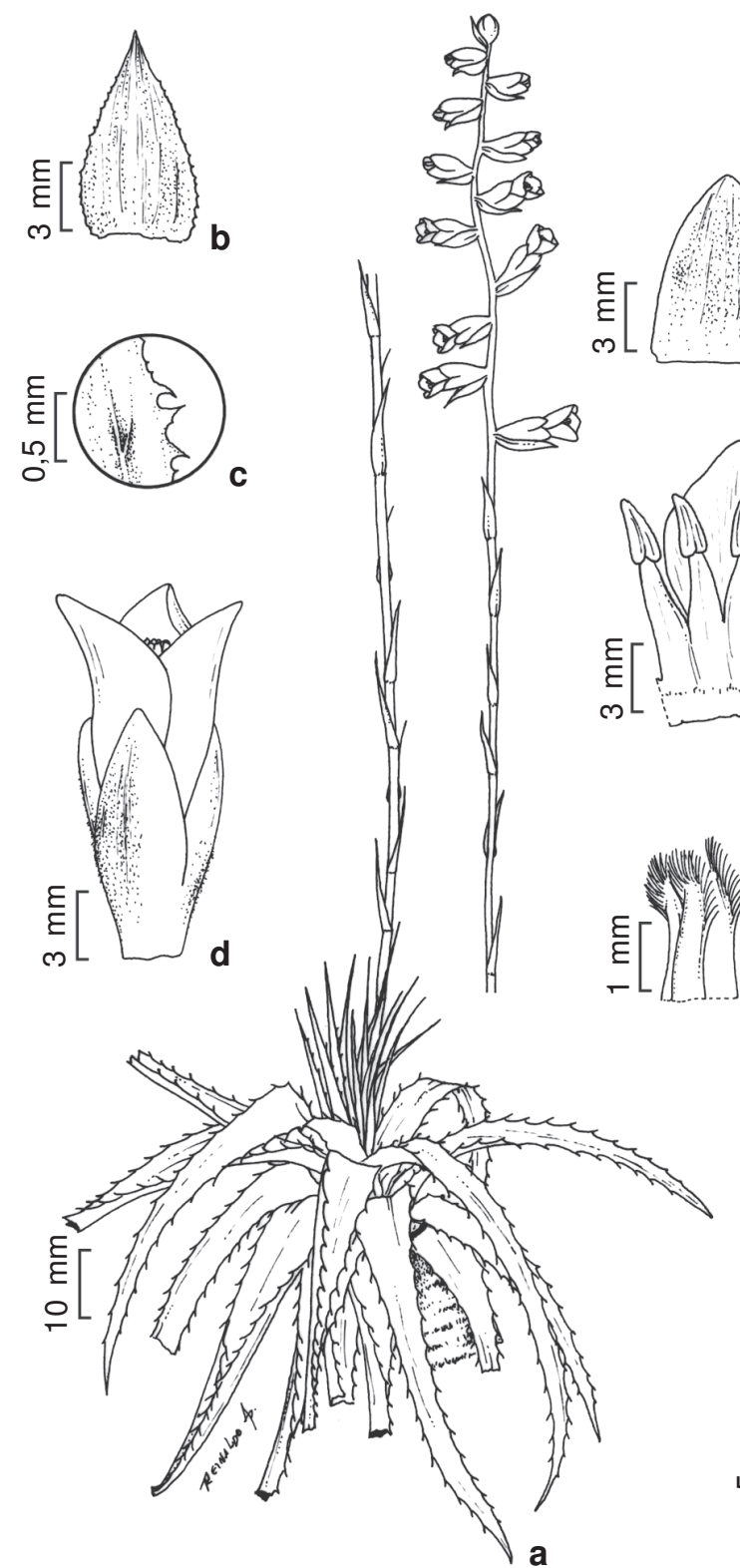
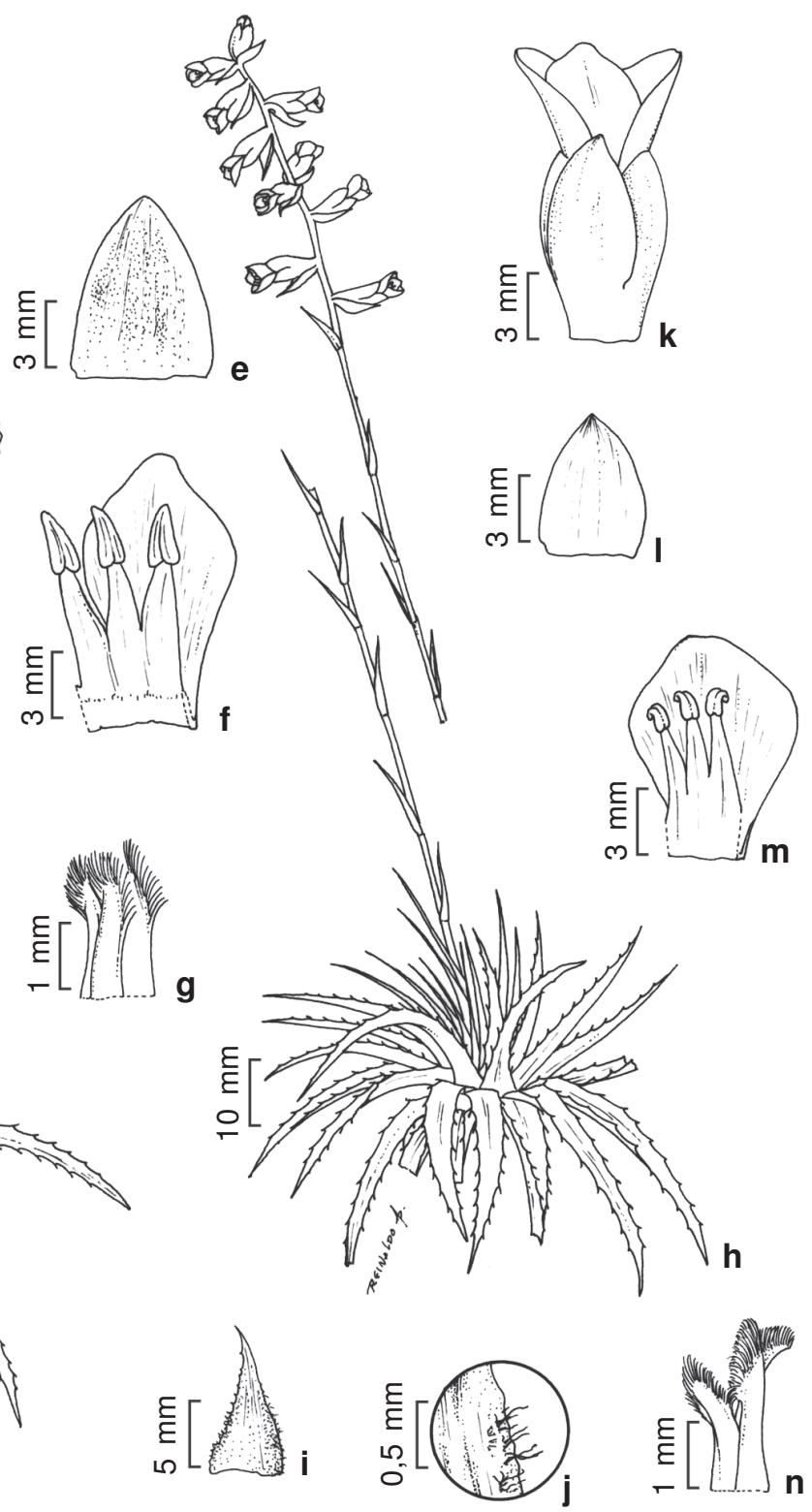

Figura 4 - a-g. Dyckia saxatilis Mez - a. hábito; b. bráctea floral; c. detalhe da margem da bráctea floral; d. flor; e. sépala; f. detalhe da pétala com estames; g. estigma conduplicado-espiral (Guarçoni 1282). h-n. Dyckia schwackeana Mez - h. hábito; i. bráctea floral; j. detalhe da margem da bráctea floral; k. flor; 1. sépala; m. detalhe da pétala com estames; n. estigma conduplicado-espiral (Guarçoni 1271).

Figure 4 - a-g. Dyckia saxatilis Mez - a. habit; b. floral bract; c. detail of floral bract margin; d. flower; e. sepal; f. detail of petal and stamens; g. stigma conduplicate-spiral type (Guarçoni 1282). h-n. Dyckia schwackeana Mez - h. habit; i. floral bract; j. detail of floral bract margin; k. flower; 1 . sepal; m. detail of petal and stamens; $n$. stigma conduplicate-spiral type (Guarçoni 1271). 
2,1-3,1 cm diâm., laxa; ráquis laranja a castanha, densamente cinéreo-tomentosa. Brácteas florais elípticas, $0,6-1,1 \times 0,4-0,6 \mathrm{~cm}$, menores que as sépalas, laranja com ápice castanho a vermelho, cinéreo-lepidotas na face abaxial, fimbriadas, suberetas, carenadas, acuminadas. Flores 4-14, 0,91,2 cm compr., ca. 4 mm diâm., suberetas a patentes, pediceladas; pedicelos 1-2 mm; sépalas elípticas a ovadas, 5-7×5-8 mm, laranja a laranja-avermelhadas, cinéreo-tomentosas na face adaxial, fimbriadas, livres, agudo-apiculadas; pétalas obovadas, 7-9 × 6-9 cm, laranja, concrescidas na base, obtusas; estames inclusos, ca. $8 \mathrm{~mm}$, conatos $2-3 \mathrm{~mm}$ acima do anel pétalo-estamíneo; filetes complanados, 5-7 $\mathrm{mm}$, amarelos; anteras inclusas, triangulares, curvas no ápice, ca. $3 \mathrm{~mm}$; ovário súpero, ca. $4 \mathrm{~mm}$, verde; estilete 1-2 mm; estigma conduplicado-espiral, ca. $1 \mathrm{~mm}$, amarelo. Fruto cápsula, castanho escuro, 0,9-1,1 cm compr., 0,8-1 cm diâm.

Material examinado: BRASIL. MINAS GERAIS: Parque Estadual da Serra do Rola-Moça: Belo Horizonte, Serra do Cachimbo, 27.XI.2006, fl., E. Guarçoni 1280 (VIC). Brumadinho, Serra da Calçada, 23.X.2006, fl. e fr., $E$. Guarçoni 1326 (VIC), 27.XI.2006, fl., E. Guarçoni 12841285 (VIC). Nova Lima, Campo de Canga Couraçada, 20.IV.2007, fl., E. Guarçoni 1304 (VIC). Ibirité, Serra do Rola-Moça, 23.X.2006, fl., E. Guarçoni 1271 (VIC).

Ocorre nos Campos Rupestres da Cadeia do Espinhaço, em MG. No PESRM, Dyckia schwackeana pode ser observada como saxícola, crescendo no campo rupestre ferruginoso couraçado.

A espécie é integrante de um complexo de táxons muito semelhantes, sendo próxima de Dyckia consimilis (vide comentários desta espécie). Aproxima-se de D. simulans L.B. Sm, da qual difere por apresentar os estames conatos por ca. 2-3 mm acima do anel pétalo-estamíneo ( $v s$. livre) e inflorescência laxa (vs. densa) (Smith \& Downs 1974).

\section{Dyckia simulans L.B.Sm., Arq. Bot. Estado São} Paulo 1:108. 1943.

Fig. 5 a-h

Erva saxícola, ca. $25 \mathrm{~cm}$. Folhas numerosas, canaliculadas; bainha suborbicular, $8 \times 1 \mathrm{~mm}$, glabra, serrilhada, acúleos menores que $1 \mathrm{~mm}$, irregularmente curvos; lâmina linear, ca $3 \times 0,4 \mathrm{~cm}$, lepidota na face abaxial e no terço inferior da face adaxial, serrada, acúleos ca. $2 \mathrm{~mm}$, antrorsos, acuminado-apiculada. Escapo ereto, ca. $18,6 \mathrm{~cm}$ compr., ca. 3 mm diâm., glabro. Brácteas escapais ovadas, ca. $8 \times 3-4 \mathrm{~mm}$, inferiores ligeiramente maiores que os entrenós, densamente lepidotas na face abaxial, serradas, acúleos menores que $1 \mathrm{~mm}$, carenadas, acuminadas. Inflorescência simples, ereta, ca. 2,9 cm, congesta. Brácteas florais ovadas a elípticas, ca. $7 \times 3,5 \mathrm{~mm}$, menores que as sépalas, densamente lepidota na face abaxial, serrilhadas, carenadas, agudas. Flores 12, ca. 1,3 cm compr., suberetas, pediceladas; pedicelo ca. $4 \mathrm{~mm}$ compr.; sépalas ovadas, assimétricas, 6-7 × 4-5 mm, avermelhadas, glabras, fimbriadas, livres, agudas; pétalas obovadas, $9 \times 7-8 \mathrm{~mm}$, avermelhadas, concrescidas na base, obtusas; estames inclusos, livres acima do anel pétalo-estamíneo; filetes complanados, ca. $6 \mathrm{~mm}$; anteras triangular, ca. $3 \mathrm{~mm}$; ovário súpero, 3-4 mm compr.; estilete ca. 2,31 mm compr.; estigma conduplicado-espiral, ca. 1,5 mm. Frutos cápsula.

Material examinado: BRASIL. MINAS GERAIS: Parque Estadual da Serra do Rola-Moça: Brumadinho, Retiro das Pedras, Serra da Calçada, 06.XI.2001, fl., P.L. Viana 374 (BHCB).

Ocorre nos Campos Rupestres, em MG. No PESRM, durante nossos estudos, a espécie não foi observada.

Dyckia simulans aproxima-se de D. schwackeana, diferindo desta por apresentar escapo glabro ( $v s$. tomentoso), inflorescência congesta ( $v s$. laxa) e estames livres acima do anel pétalo-estamíneo ( $v s$. conatos 2-3 mm).

Espécie conhecida até o momento para a região do Quadrilátero Ferrífero.

14. Dyckia tenebrosa Leme \& H. Luther, Selbyana 19(2): 183. 1999.

Fig. 6 a-g

Erva saxícola, 54,5-68 cm. Folhas 20-27, suculentas, inferiores patente-arqueadas, superiores suberetas, canaliculadas; bainha oblonga a ligeiramente ovadas, 1-1,9×1,4-2,4 cm, branco-esverdeada, esparsamente lepidota na face abaxial, serrilhada, acúleos menores que $1 \mathrm{~mm}$, irregularmente curvos; lâmina linear-triangular, 12,4-14,6×0,8-1,4 cm, verde-escura a vinácea com margem castanha, densamente cinéreo-lepidota na face abaxial, serrada, acúleos ca. $2 \mathrm{~mm}$, retrorsos, acuminado-apiculada. Escapo ereto, 47-49,7 cm compr., ca. 4 mm diâm., verde-escuro, metade inferior inconspicuamente branco-tomentoso, metade superior densamente branco-tomentoso. Brácteas escapais ovadas, $0,6-3,9 \times 0,3-0,5 \mathrm{~cm}$, inferiores maiores que os entrenós, superiores menores, verdes com máculas vermelhas e margens castanhas, densamente branco-lepidota com bandas ferrugíneas na face abaxial e incospicuamente lepidota na face adaxial, inteiras, carenadas, acuminadas. Inflorescência simples, ereta, 12,5-28,5 cm; ráquis densamente brancotomentosa. Brácteas florais amplamente ovadas, 8 $\times 8 \mathrm{~mm}$, menores que as sépalas, verdes com 


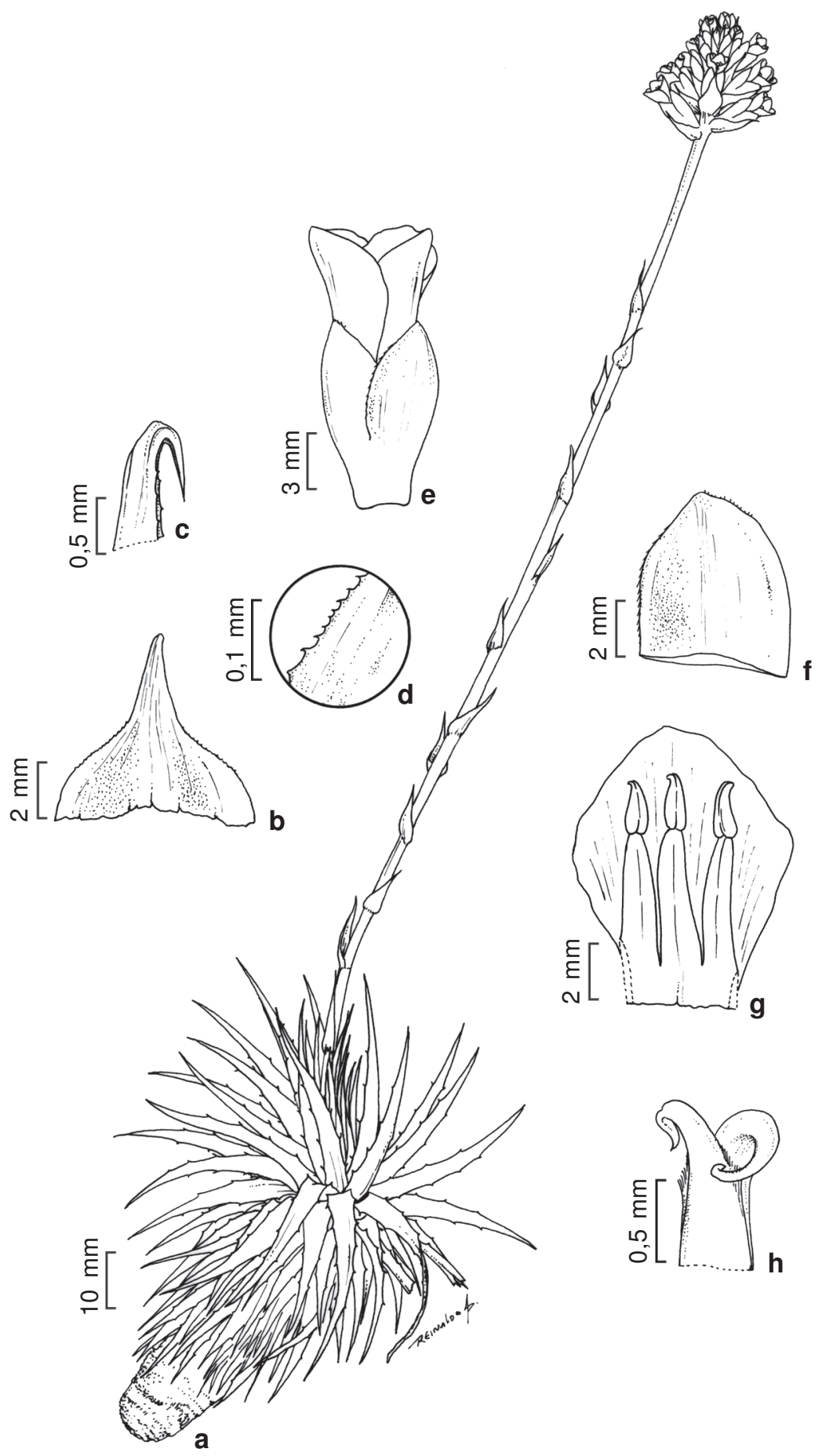

Figura 5 - a-h. Dyckia simulans L.B.Sm - a. hábito; b. bráctea floral; c. detalhe do ápice da bráctea floral; d. detalhe da margem da bráctea floral; e. flor; f. sépala; g. detalhe da pétala com estames; h. estigma conduplicado-espiral (Viana 374).

Figure 5 - a-h. Dyckia simulans L.B.Sm - a. habit; b. floral bract; c. detail of floral bract apex; d. detail of floral bract margin; e. flower; f. sepal; g. detail of petal and stamens; h. stigma conduplicate-spiral type (Viana 374). 


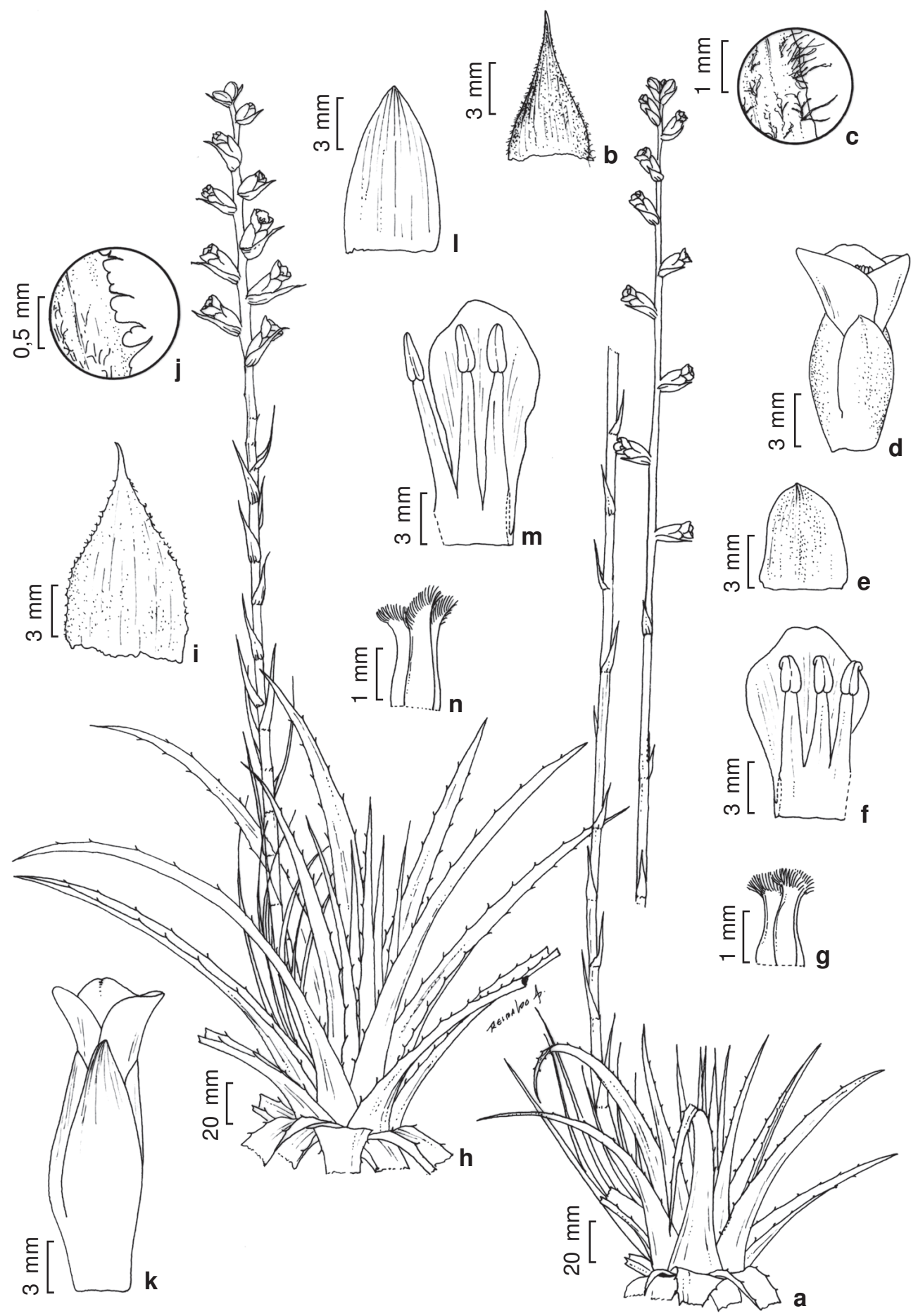

Figuras 6 - a-g. Dyckia tenebrosa Leme \& H. Luther - a. hábito; b. bráctea floral; c. detalhe da margem da bráctea floral; d. flor; e. sépala; f. detalhe da pétala com estames; g. estigma conduplicado-espiral (Guarçoni 1306). h-n. Dyckia trichostachya Baker - h. hábito; i. bráctea floral; j. detalhe da margem da bráctea floral; k. flor; 1. sépala; m. detalhe da pétala com estames; n. estigma conduplicado-espiral (Guarçoni 1260).

Figure 6 - a-g. Dyckia tenebrosa Leme \& H. Luther - a. habit; b. floral bract; c. detail of floral bract margin; d. flower; e. sepal; f. detail of petal and stamens; g. stigma conduplicate-spiral type (Guarçoni 1306). h-n. Dyckia trichostachya Baker - h. habit; i. floral bract; j. detail of floral bract margin; k. flower; 1. sepal; m. detail of petal and stamens; n. stigma conduplicate-spiral type (Guarçoni 1260). 
margens pintalgadas de vermelho, densamente lepidota na face abaxial, inteiras, carenadas, acuminadas. Flores 16-20, 1,3-1,8 cm compr., 6-9 mm diâm., suberetas a patentes, pediceladas; pedicelo 4-7 mm, densamente cinéreo-lepidoto; sépalas ovadas a elípticas, 5-6×3-5 mm, verdes ou verde-acastanhadas com margens pintalgadas de vermelho na face adaxial, densamente lepidotas na face abaxial, fimbriadas, livres, obtusas; pétalas obovadas a espatuladas, 0,9-1,2 × 0,4-1 cm, castanho-escuras, concrescidas na base, obtusas: estames excedendo as pétalas por uma fração da antera, livres acima do anel pétalo-estamíneo; filetes complanados, 7-9 mm, amarelo-alvo; anteras sagitadas, ca. 2,5 mm; fortemente curvas, basifixas; ovário súpero, 4-6 mm compr., 2-3 mm diâm., amarelo; estilete muito curto; estigma conduplicadoespiral, ca. $2 \mathrm{~mm}$, castanho. Frutos cápsula.

Material examinado: BRASIL. MINAS GERAIS: Parque Estadual da Serra do Rola-Moça: Belo Horizonte, Serra do Cachimbo, 20.IV.2007, fl., E. Guarçoni 1306 (VIC). Brumadinho, próximo ao Retiro das Pedras, 04.III.2006, fl., E. Guarçoni 1244-1245 (VIC). Nova Lima, Serra do Cachimbo, 27.XI.2006, fl. cult., E. Guarçoni 1305 (VIC).

Ocorre nos Campos Rupestres, em MG. No PESRM foi observada como saxícola no campo rupestre ferruginoso couraçado ou no campo graminoso quartzito.

Espécie de fácil identificação pela coloração castanho-escura de suas pétalas. Dyckia tenebrosa aproxima-se de D. machrisiana L.B.Sm., que não ocorre no Parque, diferindo desta por apresentar 1/3 de seu tamanho, lâmina foliar glabra na face adaxial, inflorescência branco-tomentosa e brácteas florais maiores (Leme \& Luther 1998). Dyckia tenebrosa também lembra $D$. saxatilis Mez, diferindo desta por apresentar brácteas florais maiores, pedicelos menores (2-3vs. 4-7 mm), pétalas de coloração vinho e estilete muito pequeno.

Dyckia tenebrosa era conhecida até o momento para a região de Andrequicé e Diamantina. Sua localização na Serra do Cachimbo (PESRM) amplia sua área de ocorrência. Estudos florísticos em outras regiões da Cadeia do Espinhaço são necessários para o conhecimento do real status de conservação da espécie.

15. Dyckia trichostachya Baker, Handb. Bromel. 133. 1889.

Fig. 6 h-n

Erva terrestre, ca. $77,3 \mathrm{~cm}$. Folhas numerosas, basais patentes e apicais eretas, suculentas; bainha oblonga ou elíptica, 1,8-2,9×2,6-4,1 cm, branca a creme-esverdeada, serrilhada, acúleos menores que $1 \mathrm{~mm}$, retrorsos; lâmina linear-triangular, 22-39,7 × 1,1-1,2 cm, verde, lepidota nas duas faces, serrada, acúleos 1-2 mm, antrorso-uncinados, canaliculadas, acuminado-apiculada. Escapo ereto a tortuoso, 30,4-57,8 cm compr., 0,5-1 cm diâm., verde ou castanho, ferrugíneo-tomentoso. Brácteas escapais elípticas a ovadas, inferiores 10,4-20,9 ×0,2-2 cm, imbricadas, superiores $2,6-7,7 \times 0,7-0,9 \mathrm{~cm}$, maiores que os entrenós, superiores ligeiramente esparsas, verdes, densamente lepidotas na face abaxial, serrilhadas, acúleos menores que $1 \mathrm{~mm}$, antrorsos, acuminado-apiculadas. Inflorescência simples, ereta, 16,2-29 cm; ráquis densamente ferrugíneotomentosa. Brácteas florais largo-elípticas a ovadas, $1-3,8 \times 0,6-1,4 \mathrm{~cm}$, inferiores maiores que as flores, superiores iguais as sépalas, densamente brancolepidotas na face abaxial, serrilhadas, acúleos menores que $1 \mathrm{~mm}$, suberetas, carenadas, agudoapiculadas. Flores numerosas, eretas, pediceladas; pedicelo 3-6 mm compr., 3-5 mm diâm., densamente lepidoto; sépalas ovadas a elípticas, 0,9-1,1×0,5$0,6 \mathrm{~cm}$, densamente lepidotas na face abaxial, fimbriadas, livres, agudo-apiculadas; pétalas obovadas, 1,3-1,4×0,5-0,6 cm, superfície ondulada na região apical, concrescidas na base, obtusas; estames inclusos, livres acima do anel pétaloestamíneo; filetes complanados, 7-9 mm; anteras lineares; ovário súpero, 4-6 mm; estilete 1-2 mm; estigma conduplicado-espiral, menor que $1 \mathrm{~mm}$. Fruto cápsula, 0,9-1,4 cm compr., 7-9 mm diâm., castanho-escuro a preto.

Material examinado: BRASIL. MINAS GERAIS: Parque Estadual da Serra do Rola-Moça: Brumadinho, Retiro das Pedras, Serra da Calçada, sd., fl., L.A. Martens 63 (SPF), 05.II.2002, fl., P.L. Viana 500 (BHCB); próximo ao Retiro das Pedras, 26.VII.2006, fr. e fl., E. Guarçoni 1260 (VIC), 01.VIII.2007, fr., E. Guarçoni 1303 (VIC).

Ocorre em MG e no ES. Em MG ocorre nos Campos Rupestres da Cadeia do Espinhaço. No PESRM, Dyckia trichostachya é encontrada na Serra da Calçada, próximo ao Retiro das Pedras, como terrestre, em pequenos platôs arenosos entre os afloramentos rochosos dos Campos Rupestres Quartzíticos, em populações de poucos indivíduos esparsamente distribuídos.

Pode ser facilmente confundida com Dyckia bracteata (Wittm.) Mez ou D. minarum Mez, diferindo destas por apresentar filetes livres acima do anel pétalo-estamíneo ( $v s$. conatos) e anteras lineares ( $v s$. oblonga e triangular, respectivamente). Também pode ser diferenciada de $D$. bracteata pelas brácteas escapais e florais amplamente ovadas 
(vs. estreito ovadas) e acúleos laxamente distribuídos pelas partes foliáceas ( $v s$. subdensamente).

16. Eduandrea selloana (Baker) Leme, W.Till, G.K.Br., J.R.Grant \& Govaerts, J. Bromeliad Soc. 58(2). 2008.

Erva terrestre, 39-48cm. Folhas 11-19, herbáceas, arqueadas; bainha ligeiramente elíptica a ovada, 6-7,5 $\times 1,6-2 \mathrm{~cm}$, creme a verde claro, densamente lepidota, inteira; lâmina linear, 58,5-70,5 ×1,1-1,6 cm, verdeescura, densamente branco-lepidota na face abaxial, inteira, canaliculada, acuminada. Escapo ereto a subereto durante a antese, 29,2-35,2 cm compr., 0,4 $-0,7$ cm diâm., verde-claro, esparsamente lepidoto na metade inferior, densamente lepidoto na metade superior. Brácteas escapais linear-lanceoladas a lanceoladas, 4,5-38,1 ×0,6-1,3 cm, inferiores maiores e eretas, superiores menores e suberetas a patentes, verde-escuras, densamente cinéreolepidotas na face abaxial, inteiras, abraçando o escapo na base, acuminadas. Inflorescência composta, subglobosa a elipsóide, 3,6-7,8 cm compr., 3,8-6,6 cm diâm.; ráquis verde, densamente branco-lepidota. Brácteas primárias ovadas, 2-4,6 $\times 1,1-1,4 \mathrm{~cm}$, as basais excedendo os fascículos, verdes, densamente branco-lepidotas na face abaxial, esparsamente branco-lepidotas na face adaxial, serrilhadas, acúleos menores que $1 \mathrm{~mm}$, acuminadas; ramos 4-11 flores, 2-2,8 cm, curtopedunculados. Brácteas florais triangulares, 1,1-1,3× 0,6-0,8 cm, verdes, densamente branco-lepidotas, ligeiramente serrilhadas, carenadas próximo ao ápice, agudas. Flores 40-54, 1,9-2,9 cm compr., sésseis; sépalas oblongas, $1-1,3 \times 0,4-0,5 \mathrm{~cm}$, verdes, lepidotas na face abaxial, inteiras, conatas por ca. 2mm, agudo-apiculadas; pétalas espatuladas, 1,4$1,7 \times 0,5-0,7 \mathrm{~cm}$, brancas com margens e ápice azul ou violeta na antese, pós-antese lilás, conatas por 1-2 cm, providas de duas calosidades, agudas; filetes complanados, adnatos ao tubo da corola, $8-12 \mathrm{~mm}$; anteras sublineares, curvas no ápice, ca. $4 \mathrm{~mm}$, dorsifixas; ovário ínfero, 0,4-1 cm compr., 6-7 mm diâm., verde-claro; estigma conduplicado-espiral, 1,7-2,2 mm, branco. Fruto bacáceo, globoso, 7-10 mm diâm., verde-escuro a verde-azulado na maturidade, com odor de maçã verde.

Material examinado: BRASIL. MINAS GERAIS: Nova Lima, Parque Estadual da Serra do Rola-Moça, Manancial do Mutuca, COPASA, 16.VI.2006, fr., E. Guarçoni 12561257 (VIC); Ponto de Captação de Água da COPASA (1146m alt.), 19.XII.2006, fl., E. Guarçoni 1289-1291 (VIC).
Ocorre nas Matas de Galeria da Cadeia do Espinhaço de MG (Serra de Ouro Preto, Antônio Pereira, Serra do Cipó-Jaboticatubas, Palácio, Rio Acima, Santa Bárbara e Santana do Riacho) (Brown \& Leme 2005). No PESRM, Eduandrea selloana foi localizada na APE-Mutuca(PESRM), em Nova Lima, às margens do rio Mutuca, ampliando sua área de ocorrência. Neste local, E. selloana ocorre em áreas de Floresta Estacional Semidecidual Montana formando touceiras com formato ligeiramente retangulares, com perfilhos suberetos. Apresenta-se como terrestre, à sombra ou em luz difusa. Ocorre em ambientes extremamente úmidos, em solo argiloso, geralmente na região mediana dos barrancos dos cursos d'água perenes (Guarçoni \& Paula 2008).

Eduandrea selloana pode ser caracterizada por espesso rizoma com abundantes raízes; folhas com superfície abaxial coberta com uma densa camada de tricomas brancos e margens inteiras; ráquis visível devido à separação dos ramos basais dos terminais e frutos subglobosos, verdes, perfumados com odor de maçã-verde.

17. Pitcairnia lanuginosa Ruiz \& Pav., Fl. Peruv. 3:35. 1802.

Erva terrestre, 53,3-91,2 cm, esciófila, acaulescente. Folhas ca. 12, membranáceas, dímórficas, suberetas; bainha ovada, 0,8-3,1 × 1,2$1,8 \mathrm{~cm}$, verde, branco-lepidota abaxialmente, inteira; lâmina linear, 48,2-87,6 cm, canaliculada, verde, densamente branco-lepidota abaxialmente, glabra adaxialmente, espinescente na base, espinhos castanhos, $2 \mathrm{~mm}$, agudo. Escapo ereto a subereto, verde, 47,6-89,4 cm comp., 5,6-6,4 mm diam., brancolanuginoso; brácteas escapais lineares, maiores que os entrenós, 16-25,8 cm, verdes, densamente branco-lepidotas na face abaxial, glabra na face adaxial, inteiras, agudas. Inflorescência simples, 10-11,6 cm, branco-lanuginosa; raquis castanha. Brácteas florais ovadas, 2,7-5,8 ×2,7-3,4 mm, menores que as sépalas, castanhas, brancolepidotas na face abaxial, glabra na face adaxial inteiras, agudas. Flores 7-10, suberetas, dísticas, em racemo, 4,9-5,3 cm comp, pedicelada; pedicelo 5,1-6,7 mm compr., 2,6 mm diam., castanho, brancotomentoso; sépalas lineares, 1,7-1,8 cm, castanhas, densamente branco-tomentosas, fimbriadas, suculentas, livres, agudas; pétalas lineares, 4-4,5 $\times 0,4-0,5 \mathrm{~cm}$, verde-avermelhadas na antese, inteiras, livres, presença de um par de apêndices petalíneos, agudo; apêndices petalíneos ovados, 2,1 mm comp., amarelos, truncados; estames 
inclusos, livres, amarelos; filetes $2 \mathrm{~cm}$ de comp.; anteras oblongas, 19,1 mm comp., amarelas, dorsifixas; ovário súpero, amarelo, 6,3 mm comp.; estilete $2,7 \mathrm{~cm}$ compr, exserto, amarelo; estigma amarelo, 2,2 mm compr. Frutos cápsula.

Material examinado: BRASIL. MINAS GERAIS: Parque Estadual da Serra do Rola-Moça: Belo Horizonte, Barreiro (2001'05,2" e 4400'14,7'), 14.III.2007, fl. cult., E. Guarçoni 1327 (VIC); Belo Horizonte, Barreiro (2001'05,2" e 4400'14,7'), 14.III.2007, fl. cult., E. Guarçoni 1328 (VIC).

Ocorre na Bolívia, Brasil ePeru. No Brasil localizase nos estados do AM, DF, GO, MG, MGePA. Em MG ocorre no Campo Rupestre, Cerrado e na Mata Atlântica. No PESRM, P. lanuginosa foi observada na Floresta Estacional Semidecidual da APE-Barreiro, às margens da nascente do córrego Barreiro.

Pitcairnia lanuginosa pode ser identificada por apresentar espinhos na base da lâmina foliar, escapo branco-lanuginoso, brácteas escapais maiores que os entrenós e densamente branco-lepidotas na face abaxial e inflorescência branco-lanuginosa.

Quando em floração em casa de vegetação, observou-se que as pétalas de Pitcairnia lanuginosa variam de coloração ao longo de seu desenvolvimento: verdes em botão floral, verdeavermelhadas na antese e vermelho em pós-antese.

18. Pseudananas sagenarius (Arruda) Camargo, Rev. Agric. (Piracicaba) 14(7-8): 4. 1939.

Erva terrestre, ca. 1,6 m. Folhas coriáceas, rígidas, basais suberetas e apicais eretas; bainha ovada a elíptica, 6,3-15×3,7-5,3 cm, creme, lepidota em ambas as faces, serrilhada, acúleos menores que $1 \mathrm{~mm}$; lâmina linear, 70,8-152,6×3,3-4,1 cm, verdeclara a verde-escura, lepidota em ambas as faces, laxamente serrada, acúleos 1-2 mm, antrorsouncinados, canaliculada, agudo-apiculada. Escapo ereto, 63,8-74,5 cm compr., 1,3-1,4 cm diâm., castanho-avermelhado, glabro ou densamente branco-tomentoso. Brácteas escapais lineares a triangulares, 9,9-62,5 × 1,7-3,4 cm, inferiores maiores que as superiores, verdes a avermelhadas, lepidota em ambas as faces, serradas, acúleos ca. 2 $\mathrm{mm}$, ligeiramente canaliculadas, acuminadoapiculadas. Inflorescência espiga estrobiliforme, ca. $11,8 \mathrm{~cm}$ compr., 6,2 cm diâm., sem coma apical. Brácteas florais triangulares, 2,5-3,5×0,8-1,3 cm, vermelhas, lepidotas em ambas as faces, serradas, acúleos 1-2 mm compr., acuminado-apiculadas. Flores ca. 150, 4-4,32 cm compr., sésseis; sépalas ovadas, $1-1,2 \times 0,2-0,3 \mathrm{~cm}$, vermelhas, lepidotas na face abaxial, serrilhadas, acúleos vermelhos, menores que $1 \mathrm{~mm}$, livres, assimétricas, agudoapiculadas; pétalas obovadas, 3,5-3,7 ×2-2,2 cm, violetas, livres, um par de calosidades, obtusas; estames inclusos, 2,5-3 cm, adnatos às pétalas; filetes brancos, cilíndricos; antera linear, 5-6 mm, branca, basifixa; ovário ínfero, verde, fundido aos demais; estilete ca. 1,5 cm, branco; estigma conduplicado-espiral, ca. $2 \mathrm{~mm}$. Fruto composto, suculento, ca. 17,1 cm compr., ca. 9,9 cm diâm., odor adocicado.

Material examinado: BRASIL. MINAS GERAIS: Parque Estadual da Serra do Rola-Moça: Nova Lima, Ponto de Captação de Água da COPASA - Mutuca (1129 m), 15.II.2007, fr., E. Guarçoni 1292 (VIC); Manancial do Mutuca, COPASA, 16.XI.2007, fl., E. Guarçoni 1322 (VIC).

Ocorre na Argentina, Bolívia, Brasil, Equador e Paraguai. No Brasil localiza-se nos estados da AL, BA, CE, ES, MG, MT, MS, PR, PE, RJ, SC e SP. Segundo dados de herbário (R 109.104), a espécie apresenta uma coleta para o RS, o que amplia sua área de ocorrência. Em MG ocorre na Mata Atlântica e no Cerrado. No PESRM, Pseudananas sagenarius foi observada somente na Floresta Estacional Semidecidual, na APE-Mutuca, nas margens dos cursos d'água.

Pode ser facilmente confundida com espécies do gênero Ananas, diferindo destas pela ausência de coma apical no ápice da inflorescência ( $v s$. presença), nunca produzindo perfilhos basais ( $v s$. produzindo) e rizomas presentes (vs. ausentes).

19. Tillandsia gardneri Lindl., Bot. Reg. 28: 63. 1842.

Erva epífita, 21,2-23,6 cm. Folhas numerosas, ca. 30; bainha oblonga, $0,8-1,1 \times 1,6-1,9 \mathrm{~cm}$, verdeclara, cinéreo-lepidota na face abaxial, inteira; lâmina longo-triangular, 13,6-25,4×3,8-5,12 cm, verde-acinzentada, densamente lepidota, inteira, canaliculada, acuminada. Escapo pêndulo, 12,5-13,7 cm compr., ca. 4 mm diâm., verde-claro, densamente lepidoto. Brácteas escapais lanceoladas, 11,1-16,3 $\times 0,5-0,7 \mathrm{~cm}$, verde-acinzentadas, densamente lepidotas, inteiras, envolvendo todo o escapo, canaliculadas, acuminadas. Inflorescência composta, pendente, 6,3-6,5 cm compr., 5,4-6,6 cm diâm.; ráquis verde, densamente lepidota. Brácteas primárias ovadas a elípticas, 2-4,3 ×0,6-1,1 cm, verde-claras a róseas, lepidotas na face abaxial e na extremidade da face adaxial, inteiras, acuminadas. Brácteas florais elípticas, 1,1-2,2 ×0,5-1 cm, verdeclaras a róseas, lepidotas na face abaxial e na extremidade da face adaxial, inteiras, acuminadas. Flores ca. 26, 1,4 $1,7 \mathrm{~cm}$, sésseis; sépalas elípticas, $1,2-1,5 \times 0,3-0,5 \mathrm{~cm}$, 
verde-claras, lepidotas na face abaxial, inteiras, acuminadas; pétalas espatuladas, 1,4-1,6×0,3-0,4 cm, róseas a roxas, marrons na pós-antese, livres, obtusas; estames inclusos, 1,3-1,6 cm, livres; filetes complanados, 1,1-1,3 cm, verde-pálido; anteras 2-3 mm, amarelas; ovário súpero, ca. $4 \mathrm{~mm}$, verde; estilete branco, ca. 1,4cm; estigma simples-ereto, 1-2 mm. Fruto cápsula, verde-acinzentado, 2,9-3,1 cm compr., ca. 4 mm diâm. Material examinado: BRASIL. MINAS GERAIS: Parque Estadual da Serra do Rola-Moça: Belo Horizonte, Manancial do Barreiro, COPASA, 20.IV.2006, fl., E. Guarçoni 1307 (VIC). Brumadinho, Manancial da Catarina, COPASA, 20.IX.2006, fr., $R$. Guarçoni \& B. Rodrigues 1266 (VIC). Nova Lima, Faz. da Mutuca, 27.III.1933, fl., M. Barreto 4910 (R).

Ocorre da Colômbia ao Brasil. No Brasil pode ser encontrada nos seguintes estados: BA, CE, ES, MG, PB, PE, PI, PR, RJ, RS, SC, SPe SE. Em MGocorre nos Campos Rupestres, na Mata Atlântica e no Cerrado. No PESRM, Tillandsia gardneri pode ser localizada nas Florestas Estacionais Semideciduais, geralmente nas áreas abertas, e nos capões de mata dos Campos Rupestres Ferruginosos.

Espécie de tamanho variado, muitas vezes assemelhando-se a Tillandsia geminiflora em função de seu aspecto vegetativo, podendo ser separada por possuir brácteas florais maiores que as sépalas, folhas verde-prateadas ( $v s$. verdeavermelhadas), inflorescência densa e globosa ( $v s$. subpiramidal) e ráquis oculta pelas brácteas florais (vs. ráquis exposta).

Luther (2006) cita para a espécie três variedades. No PESRM observa-se a Tillandsia gardneri var. virescens E. Pereira, por apresentar brácteas florais e escapais verdes.

20. Tillandsia recurvata (L.) L., Sp. Pl. ed. 2. 410. 1762.

Erva epífita, 7,6-14,6 cm. Folhas 5-11, dísticas, recurvadas; bainha elíptica ou ovada, $0,8 \times 2 \mathrm{~cm}$, verde, densamente lepidota na face abaxial, inteira; lâmina linear, 5,6-8,2×0,1 cm, verde, densamente lepidota em ambas as faces, inteira, canaliculada, acuminada. Escapo ereto, 3,9-5,2 cm, verde, densamente lepidoto. Brácteas escapais lanceoladas, 0,7-1,3×0,1 cm, verdes, densamente lepidotas na face abaxial, inteira, uma por escapo, acuminadas. Inflorescência uniflora. Bráctea floral ovada a oblonga, 0,5-1 $\times 0,2 \mathrm{~cm}$, verde, brancolepidota na face abaxial, inteira, envolvendo parcialmente as sépalas, acuminada. Flores ca. 1,6 cm compr., ca. 4 mm diâm., pedicelada; pedicelo ca. $6 \mathrm{~mm}$; sépalas elípticas a oblongas, $6-7 \times 2 \mathrm{~mm}$, castanhas, conatas na base, agudas; pétalas espatuladas, $1,1 \times 0,1 \mathrm{~cm}$, violáceas, livres, recurvadas no ápice, obtusas; estames inclusos, ca. $5 \mathrm{~mm}$, livres; filetes delgados, ca. $4 \mathrm{~mm}$, brancos; anteras oblongas, menores que $1 \mathrm{~mm}$, amarelas, basifixas; ovário súpero, ca. 2 mm compr., verde; estilete ca. $1 \mathrm{~mm}$, verde; estigma simples-ereto, ca. $1 \mathrm{~mm}$, amarelo. Fruto cápsula, 2,2-1,3 cm, castanho. Material examinado: BRASIL. MINAS GERAIS: Parque Estadual da Serra do Rola-Moça: Belo Horizonte, Manancial do Barreiro, COPASA, 16.VIII.2007, fl., E. Guarçoni 1325 (VIC). Brumadinho, Retiro das Pedras, 29.V.2001, fr., P.L. Viana 71 (BHCB); Manancial da Catarina, COPASA, 26.VII.2006, fl., E. Guarçoni 1324 (VIC). Ibirité, Pitangueiras (1093m), 31.VII.2007, fr., E. Guarçoni 1301 (VIC).

Ocorre do sul dos Estados Unidos até a Argentina. No Brasil ocorre nos estados de AL, BA, CE, MG, PA, PB, PE, PR, RJ, RS, SC, SP, RN. Em MG pode ser encontrada na Caatinga, Cerrado, Campos Rupestres e Mata Atlântica. No PESRM, é encontrada como epífita nas Florestas Estacionais Semideciduais. Viana \& Lombardi (2007) citam a ocorrência da espécie para a Serra da Calçada, no Campo Rupestre Ferruginoso, dentro de capão de mata.

Apresenta grande afinidade com Tillandsia mallemontii Glaziou ex Mez, da qual difere por apresentar sépalas menores (6-7 mm vs. $12 \mathrm{~mm}$ ) e pétalas espatuladas (vs. suborbiculares). Paula (1998) cita ainda como diferença as pétalas estreitas ( $v s$. largas), inconspícuas (vs. conspícuas) e o limbo foliar cilíndrico densamente cinéreo-lepidoto ( $v s$. aplainado).

21. Tillandsia stricta Sol. Bot. Mag. 37: t. 1529. 1813.

Erva epífita, 11,8-15 cm. Folhas numerosas; bainha oblonga, $0,5-1,6 \times 0,7-1,2 \mathrm{~cm}$, branca a branco-esverdeada, densamente lepidota na metade superior de ambas as faces, inteira, distinta da lâmina por uma leve constricção; lâmina lineartriangular, 5,9-12,3×0,4-1,0 cm, verde-acinzentada, densamente lepidota em ambas as faces, inteira, canaliculada, acuminada. Escapo pêndulo, 5,6-8,3 cm compr., 2-3 mm diâm., verde-claro a verde. Brácteas escapais elípticas a ovadas, 4-9,2 × 0,8-1 $\mathrm{cm}$, verde-claras a verde-acinzentadas, densamente lepidotas na face abaxial, inteiras, agudas. Inflorescência simples, ca. $6 \mathrm{~cm}$ compr., ca. $4 \mathrm{~cm}$ diam; ráquis verde, densamente lepidota. Brácteas florais ovadas, 1,2-4×0,7-1,5 cm, inferiores maiores que superiores, róseas a verde-claras, inteiras, glabras a ligeiramente lepidotas no ápice da face abaxial, acuminadas. Flores 9-18; sépalas ovadas a 
lanceoladas, ca. 0,6-1 × 0,3-0,6 cm, róseas, densamente lepidotas na face abaxial, inteiras, conatas na base 3-4 mm, agudas; pétalas lanceoladas, $1,2-1,3 \times 0,2-0,3 \mathrm{~cm}$, azuis a roxas, inteiras, obtusas; estames inclusos; filetes plicados, 6-7 mm, brancos; anteras menores $1 \mathrm{~mm}$, brancas; ovário súpero, cilíndrico, 2-3 mm, verde-claro; estigma simplesereto, acima das anteras. Fruto cápsula.

Material examinado: BRASIL. MINAS GERAIS: Parque Estadual da Serra do Rola-Moça: Belo Horizonte, Barreiro, Ponto de Captação de água da COPASA, Barreiro (1107 m), 15.III.2007, fl., E. Guarçoni 1299 (VIC). Brumadinho, Manancial da Catarina, COPASA, 28.VIII.2006, fl., E. Guarçoni 1267 \& Rodrigues (VIC). Nova Lima, Rio da água da chuva, 20.IV.2006, fl., E. Guarçoni 1265 (VIC).

Ocorre na América do Sul e Trinidad. No Brasil, ocorre nos seguintes estados: BA, ES, MG, PR, RJ, RS, SC, SP e PE. Em MG pode ser encontrada nos Campos Rupestres, Cerrado e Mata Atlântica. No PESRM, Tillandsia stricta é encontrada na Floresta Estacional Semidecidual, tanto na sombra quanto ao sol, geralmente nas áreas abertas da mata.

22. Vriesea longistaminea Paula \& Leme, Vidalia 1(2): 25.2004.

Erva terrestre, ca. $116 \mathrm{~cm}$, esciófila, propagando-se por brotações axilares. Folhas ca. 20 , coriáceas, patentes a suberetas, formando rosetas infundibuliformes; bainha elíptica, 10,3-11,9 $\times 6,4-7,4 \mathrm{~cm}$, verde com máculas vináceas em ambas as faces, glabra, inteira; lâmina linear, 5,4-5,8 × 2,1$3,9 \mathrm{~cm}$, levemente canaliculada, verde com mácula vinácea em ambas as faces, glabra, inteira, aguda. Escapo ereto, verde com mácula vinácea, $99,1 \mathrm{~cm}$ comp., 4,07 mm diam., glabro. Brácteas escapais lineares, abraçando todo o escapo, inferiores maiores que os entrenós, 7-9,4 × 0,8-1,3 cm, superiores menores que os entrenós $3,0-6,4 \times 0,8$, verdes com máculas vináceas, glabras, inteiras, agudas. Inflorescência simples, geniculada, $17,3 \mathrm{~cm}$; raque verde com mácula vinácea. Brácteas florais elípticas, 2,54-2,16×1,77 cm, coriáceas, carenadas, menores que as sépalas, verdes com mácula vinácea, vinácea nas margens, inteiras, agudas. Flores ca. 9, suberetas, dísticas, em racemo, 6,19$6,97 \mathrm{~cm}$ comp, pediceladas; pedicelo $1,1 \mathrm{~cm}$ compr., $6 \mathrm{~mm}$ diam., verde; sépalas elípticas, $3,4 \times 1,1 \mathrm{~cm}$, verdes com margens vináceas, inteiras, ligeiramente coriáceas, livres, agudas; pétalas elípticas, 4,1 $\times$ $1,4 \mathrm{~cm}$, amarela com ligeiras manchas vináceas, inteiras, livres, presença de um par de apêndices petalíneos, agudo; apêndices petalíneos lineares, 1,2-1,4 cm comp., amarelos, agudos; estames exsertos, livres, amarelos; filetes 5,2 cm de comp., concrescidos as pétalas; anteras oblongas, $1,1 \mathrm{~cm}$ comp., amarelas, dorsifixas; ovário súpero, amarelo, ca. 7,2 mm comp.; estilete ca. 4 cm compr, exserto, amarelo; estigma lâminaconvoluta, amarelo, ca. $1 \mathrm{~mm}$ compr. Fruto cápsula. Material examinado: BRASIL. MINAS GERAIS: Parque Estadual da Serra do Rola-Moça: Brumadinho, Serra da Calçada, 27.XI.2006, fl. Cult., E. Guarçoni 1326(VIC).

Ocorre nos Campos Rupestres Ferruginosos do Quadrilátero Ferrífero, em MG. Espécie conhecida até o momento para a região de Mariana. Versieux \& Wendt (2006) citam sua ocorrência para Brumadinho, ampliando sua área de ocorrência. No PESRM somente um indivíduo foi observado, como terrestre, dentro de capão de mata.

Vriesea longistaminea pode ser facilmente confundida com V. atropurpurea Silveira (Smith \& Downs 1977). Difere desta por apresentar bráctea floral estreita, sépalas agudas (vs. obtusa), apêndices petalíneos longos e lineares (vs. ovados) (Leme \& Paula 2004).

23. Vriesea minarum L.B.Sm., Arq. Bot. Estado São Paulo 1: 118. 1943.

Erva rupícola ou saxícola, 58,9-77,5 cm. Folhas 6-10, eretas, formando roseta infundibuliforme; bainha ovada ou elíptica, 6,7-14,4 $\times 6,5-9,3 \mathrm{~cm}$, verde-clara com mácula escura na metade superior da face adaxial, lepidota, inteira; lâmina linear, 14,2-16,6 × 4,5-5,2 cm, verde com mácula castanha a roxa na face adaxial ou em ambas as faces, inteira, agudo-apiculada. Escapo ereto, castanho a castanho-avermelhado, 36,6-44,7 cm compr., 4-5 mm diâm. Brácteas escapais elípticas a lanceoladas, 3,8-4,5 ×1-1,6 cm, inferiores maiores que os entrenós, superiores menores, verdes, inteiras, agudas a acuminadas. Inflorescência simples, ereta, 9,5-27,5 cm; ráquis castanha. Brácteas florais ovadas, 1,4-1,7×1,8-2 cm, menores que as sépalas, verdes ou verde-acastanhadas, inteiras, agudas. Flores 14-32, patentes, dísticas, 3,4-4,3 cm compr., 0,9-1,2 cm diâm., pediceladas; pedicelo 5-6 mm compr., ca. $6 \mathrm{~mm}$ diâm.; sépalas ovadas a elípticas, $2,3-2,8 \times 1-1,8 \mathrm{~cm}$, verdeamareladas, inteiras, livres, agudas; pétalas oblongas, 3,1×0,6-0,8 cm, amarelas, inteiras, livres, presença de um par de apêndices petalíneos, obtusas a ligeiramente mucronadas; estames exsertos, livres, amarelos; filetes ca. 3,2 $\times 0,1 \mathrm{~cm}$; anteras oblongas, ca. $6 \times 2 \mathrm{~mm}$, amarelas, dorsifixas; ovário súpero, verde; estilete ca. $3,9 \mathrm{~cm}$, exserto, amarelo; estigma lâmina-convoluta, amarelo. Fruto cápsula. 
Material examinado: BRASIL. MINAS GERAIS: Parque Estadual da Serra do Rola-Moça: Ibirité, Serra do Rola-Moça (1392 m), 15.II.2007, fl., E. Guarçoni 1298 (VIC). Nova Lima, PESRM, Serra da Calçada, Campo Ferruginoso de Canga Couraçada, 02.III.2006, fl., E. Guarçoni 1242 (VIC); 1465 m, 02.III.2006, fl., E. Guarçoni 1243 (VIC); 20.IV.2006, E. Guarçoni 1248 (VIC).

Endêmica de MG, ocorrendo nos Campos Rupestres Ferruginosos e Quartzíticos da Cadeia do Espinhaço. No PESRM, Vriesea minarum pode ser encontrada no Campo Rupestre Ferruginoso Couraçado, como rupícola ou saxícola, em pequenas touceiras circulares.

Pode ser facilmente confundida com Vriesea stricta L.B.Sm., diferindo desta por apresentar inflorescência geralmente simples ( $v s$. composta), bráctea floral não carenada ( $v s$. fortemente carenada), sépalas agudas ( $v s$. obtusas) e por apresentar flores dísticas na antese ( $v s$. secunda).

\section{Agradecimentos}

Os autores agradecem ao E.M. C. Leme, a R. C. Forzza, e a I. R. Morrilo, o auxílio nas identificações. A Unidade de Pesquisa e Conservação de Bromeliaceae-UPCB, o uso de suas dependências e apoio logístico. Ao Instituto Estadual de Florestas IEF, a permissão de pesquisa e coleta de material botânico no Parque Estadual Serra do Rola-Moça (PESRM). A COPASA, a permissão de acesso aos mananciais sob sua administração. Aos revisores e editores, as sugestões ao manuscrito. O primeiro autor também agradece à Secretaria de Educação do Estado de Minas Gerais, a Licença concedida para freqüentar o curso de Pós-Graduação (Mestrado) da Universidade Federal de Viçosa (UFV).

\section{Referências Bibliográficas}

Brandão, M.; Ferreira, P.B.D. \& Araújo, M.G. 1997. Mais uma contribuição para o conhecimento da Cadeia do Espinhaço em Minas Gerais - VI: Serra do Rola-Moça. Daphne 7: 50-64.

Brown, G.K. \& Gilmartin, A.J. 1984. Stigma struture and variation in Bromeliaceae-neglected taxonomic characters. Brittonia 36: 364-374.

Brown, G.K. \& Gilmartin, A.J. 1989. Stigma types in Bromeliaceae. Systematic Botany 14: 110-132.

Brown, G.K. \& Leme, E.M.C. 2005. The re-establishment of Andrea (Bromeliaceae: Bromelioideae), a monotypic genus from Southeastern Brazil threatened with extinction. Taxon 54: 63-70.

Forzza, R.C. \& Wanderley, M.G.L. 1998. Flora da Serra do Cipó, Minas Gerais: Bromeliaceae - Pitcairnioideae. Boletim de Botânica da Universidade de São Paulo 17: 255-270.
Fundação Biodiversitas. 2007. Revisão das listas das espécies da flora e da fauna ameaçadas de extinção do estado de Minas Gerais. Disponível em: $<w w w . b i o d i v e r s i t a s . o r g . b r>$. Acesso em 13 abril 2007.

Giulietti, A.M.; Menezes, N.L.; Pirani, J.R.; Meguro, M. \& Wanderley, M.G.L. 1987. Flora da Serra do Cipó, Minas Gerais: Caracterização e lista de espécies. Boletim de Botânica da Universidade de São Paulo 9: 1-151.

Guarçoni, E.A.E. \& Paula, C.C. 2008. Eduandrea selloana: field notes on a new area of occurrence. Journal of the Bromeliad Society 58: 65-69.

Harley, R.M. 1995. Introduction. In: Stannard, B.L. (ed.). Flora of Pico das Almas, Chapada Diamantina-Bahia, Brazil. Royal Botanic Gardens, Kew, Richmond, Surrey. Pp. 43-78.

Holmgren, P.K. \& Holmgren, N.H. 1998. Index Herbariorum. New York Botanical Garden. Onwards (continuously updated). Disponível em: <www.sciweb.nygb.org.science2.IndexHerbariorum.asp>. Acesso em 25 agosto 2007.

IBGE. 1976. Carta IBGE 1:50.000, Folha SF-23-X-AII-2 (Brumadinho).

IBGE. 1977. Carta IBGE 1:50.000, Folha SF-23-X-AIII-1 (Rio Acima).

Jacobi, C.M.; Carmo, F.F.; Vincent, R.C. \& Stehmann, J.R. 2007. Plant communities on ironstone outcrops: a diverse and endangered Brazilian ecosystem. Biodiversity and Conservation 16: 2185-2200.

Leme, E.M.C. 2007. Three subtle new Cryptanthus species from Espinhaço Range, Minas Gerais, Brazil. Journal of the Bromeliad Society 57: 259-262.

Leme, E.M.C. \& Paula, C.C. 2004. Two new species of Brazilian Bromeliaceae. Vidalia 2: 21-29.

Leme, E.M.C. \& Luther, H.E. 1998. Miscellaneous new species of Brazilian Bromeliaceae - II. Selbyana 19: 183-190.

Luther, H.E. 2006. An Alphabetical List of Bromeliad Binomials, $10^{\text {th }}$. ed. The Bromeliad Society International, Sarasota.

Martinelli, G.; Vieira, C.M.; Gonzales, M.; Leitman, P.; Piratininga, A.; Costa, A.F. \& Forzza, R.C. 2008. Bromeliaceae da Mata Atlântica Brasileira: lista de espécies, distribuição e conservação. Rodriguésia 59: 209-258.

Meyer, S.T.; Silva, A.F.; Júnior, P.M. \& Meira-Neto, J.A.A. 2004. Composição florística da vegetação arbórea de um trecho de floresta de galeria do Parque Estadual do Rola-Moça na Região Metropolitana de Belo Horizonte, Minas Gerais, Brasil. Acta Botanica Brasilica 18: 701-709.

Morillo, I.M.R. 1996. Systematics, phylogeny, chromosome number and evolution of Cryptanthus (Bromeliaceae). Tese de Doutorado. University of Missouri, Saint Louis. 268p. 
Paula, C.C. 1998. Florística da Família Bromeliaceae no Parque Estadual da Serra do Brigadeiro, Minas Gerais, Brasil. Tese de Doutorado. Universidade Estadual Paulista, Rio Claro. 238p.

Radford, A.E.; Dickison, W.C.; Massey, J.R. \& Bell, C.R. 1974. Vascular plant systematics. Harper and Row, New York. 891p.

Rizzini, C.T. 1979. Tratado de fitogeografia do Brasil. Aspectos sociológicos e florísticos. Hucitec, Edusp, São Paulo. 374p.

Rocha, C.F.D.; Cogliatti-Carvalho, L.; Nunes-Freitas, A.F.; Rocha-Pessoa, T.C.; Dias, A.S.; Ariani, C.V. \& Morgado, L.N. 2004. Conservando uma larga porção da diversidade biológica através da conservação de Bromeliaceae. Vidalia 2: 52-68.

Smith, L.B. 1952. Bromeliáceas novas ou interessantes do Brasil Arquivos Botânicos do Estado de São Paulo 2: 195.

Smith,L.B.\& Downs, R.J. 1974. Pitcairnioideae (Bromeliaceae). Flora Neotropica Monograph 14: 1- 658.

Smith, L.B. \& Downs, R.J. 1977. Tillandsioideae (Bromeliaceae). Flora Neotropica Monograph 14: 663-1492.

Smith, L.B.\& Downs, R.J. 1979. Bromelioideae(Bromeliaceae). Flora Neotropica Monograph 14: 1493-2141.
Veloso, H.P.; Rangel-Filho, A.L.R. \& Lima, J.C.A. 1991. Classificação da vegetação brasileira, adaptada a um sistema universal. IBGE, Rio de Janeiro. 123p.

Versieux, L.M. 2005. Bromeliáceas de Minas Gerais: catálogo, distribuição geográfica e conservação. Dissertação de Mestrado. Universidade Federal do Rio de Janeiro, Rio de Janeiro. 47p.

Versieux, L.M. \& Wendt, T. 2006. Checklist of Bromeliaceae of Minas Gerais, Brazil, with notes on taxonomy and endemism. Selbyana 27: 107-146.

Versieux, L.M. \& Wendt, T. 2007. Bromeliaceae diversity and conservation in Minas Gerais state, Brazil. Biodiversity and Conservation 16: 2989-3009.

Viana, P.L. \& Lombardi, J.A. 2007. Florística e caracterização dos Campos Rupestres sobre canga na Serra da Calçada, Minas Gerais, Brasil. Rodriguésia 58: 159-177.

Wanderley, M.G.L.; Martins, S.E. 2007. Bromeliaceae. In: Wanderley, M.G.; Shepherd, G.J.; Melhem, T.S.; Giulietti, A.M. Flora fanerogâmica do estado de São Paulo. Instituto de Botânica, São Paulo. Pp. 39-161.

Wanderley, M.G.L. \& Forzza, R.C. 2003. Bromeliaceae. In: Pirani, J.R. et al. (eds.). Flora de Grão-Mongol, Minas Gerais. (Parte I). Boletim de Botânica da Universidade de São Paulo. Pp.131-139. 